DEMOGRAPHIC RESEARCH

VOLUME 44, ARTICLE 27, PAGES 627-670 PUBLISHED 31 MARCH 2021

http://www.demographic-research.org/Volumes/Vol44/27/

DOI:10.4054/DemRes.2021.44.27

Research Article

Stepfather families and children's schooling in sub-Saharan Africa: A cross-national study

Vissého Adjiwanou

Adebiyi Boco

Sanni Yaya

(C) 2021 Vissého Adjiwanou, Adebiyi Boco \& Sanni Yaya.

This open-access work is published under the terms of the Creative Commons Attribution 3.0 Germany (CC BY 3.0 DE), which permits use, reproduction, and distribution in any medium, provided the original author(s) and source are given credit.

See https://creativecommons.org/licenses/by/3.0/de/legalcode 


\section{Contents}

1 Introduction $\quad 628$

2 Marriage, divorce, and remarriage in sub-Saharan Africa 630

3 Stepfamily arrangements and children's schooling in SSA: Theoretical frameworks 631

$3.1 \quad$ Power relationships within the household 632

3.2 The model of child-rearing in SSA 633

3.3 Resource allocation within the household 634

3.4 Moderating effects 635

3.5 Hypotheses 636

4 Data and methods $\quad 636$

4.1 Problems of selection $\quad 636$

4.2 Data

4.3 Operationalization of the stepfather family arrangement 638

4.4 The dependent variable $\quad 640$

$\begin{array}{lll}4.5 & \text { Statistical analysis } & 640\end{array}$

4.6 Sensitivity analysis 641

$5 \quad$ Results $\quad 641$

5.1 School attendance by age in SSA 641

5.2 Family structure arrangement in SSA 642

5.3 Effect of stepfather family arrangement on children's schooling 643

5.4 Results from the sensitivity analysis 647

5.5 Effects of stepfather family arrangement by children's sex 647

5.6 Effects of stepfather family arrangement by children's place of residence 652

6 Discussion $\quad 654$

$\begin{array}{lr}\text { References } & 659\end{array}$

$\begin{array}{lr}\text { Appendix } & 668\end{array}$ 


\title{
Stepfather families and children's schooling in sub-Saharan Africa: A cross-national study
}

\author{
Vissého Adjiwanou ${ }^{1}$
}

Adebiyi Boco $^{2}$

Sanni Yaya ${ }^{3}$

\begin{abstract}
BACKGROUND

Research on stepfamilies and their effects on childhood investments is limited in subSaharan Africa (SSA), a region characterized by a high level of remarriage and fertility.

\section{OBJECTIVE}

The objectives of this study were to assess the prevalence of children in stepfather family arrangements and to explore the influence of this family arrangement on children's schooling.
\end{abstract}

\section{METHODS}

We rely on recent Demographic and Health Surveys (DHS) conducted in 33 SSA countries between 2006 and 2015. The study sample consists of 277,726 children aged 6 to 14. Cluster-level fixed effect models were used to predict children's school attendance status in stepfather family arrangements, in contrast with families with both biological parents or single-mother family arrangements.

\section{RESULTS}

At the regional level, the proportion of children and adolescents under 15 years of age living with stepfathers was $2.5 \%$, ranging from $1.1 \%$ in Burkina Faso to $6.3 \%$ in Gabon. In the regression analyses, children living in stepfather family arrangements were associated with lower school attendance when compared with children living with their biological parents and when compared to children in single-motherhood family arrangements. These effects are more pronounced in urban areas than in rural areas. Finally, we found that girls were not over-discriminated against in stepfather family arrangements compared to boys.

\footnotetext{
${ }^{1}$ Université du Québec à Montréal, Canada. Email: adjiwanou.visseho@uqam.ca.

2 University of Lethbridge, Canada. Email: adebiyi.boco@uleth.ca.

3 University of Ottawa, Canada.
} 


\section{CONCLUSION}

Stepfather family arrangements negatively affect children's schooling in SSA. Nonetheless, further studies for better understanding of these family arrangements are needed, as well as studies of the interactions that children have with their fathers or fathers' families.

\section{CONTRIBUTION}

This study makes an original contribution to the literature on family complexity - shedding light on the phenomenon of step-parenting - and its consequences on children's schooling in SSA.

\section{Introduction}

The family is a universal and enduring institution that provides the context within which the socialization of children occurs. Since the 1960s, the family in developed countries has been transforming in accordance with new values, as well as social, political, and economic changes (McLanahan and Percheski 2008; Beaujot 2000; Lesthaeghe 1995; Reher 2007; Sobotka 2008). Aspects of these changes include nonmarital childbearing, cohabiting unions, divorce, repartnering and remarriage, and increases in voluntary childlessness - and their impact on children and young people (Cherlin 2012; Raley and Sweeney 2020). Family transition is also under way in sub-Saharan Africa (SSA), but seemingly it is occurring at a different pace, in its own direction, and with distinctive consequences (Garenne 2014; Ohenaba-Sakyi and Takyi 2006). Previous studies have discussed various aspects of family transition patterns, including fosterage and polygyny, increases in premarital childbearing, the phenomenon of stretched households, with members living in different places, and the emergence of matrifocal families in some parts of the region (Mazzucato and Schans 2011).

Recently, the high prevalence of divorce in SSA has attracted new research that aims to understand how divorce affects various aspects of child and adolescent life (Clark and Hamplová 2013; Thiombiano, LeGrand, and Kobiané 2013; Ntoimo and Odimegwu 2014; Chae 2016; Izugbara 2016). In Burkina Faso, Thiombiano, LeGrand, and Kobiané (2013) found a higher risk of mortality under age 5 and lower school attendance among children of divorced parents relative to children who live with both biological parents. Using longitudinal data and controlling for selection bias, Chae (2016) showed that parental divorce has a negative effect on children's schooling in Malawi. Another aspect of this literature is related to single motherhood. Clark and Hamplová (2013) documented the state of single motherhood in the region and found that up to $50 \%$ of women will become single mothers at one point during their lifetime. In addition, the authors argue that the risk of child mortality is higher among children who live with formerly married mothers 
than among those who live with married women. The focus on motherhood is guided by the reality of the situation throughout the world; in most cases, children live with their mother after a divorce (Grant and Yeatman 2014). Yet this type of family arrangement is the most affected by poverty, the consequences of which continue throughout children's lives (McLanahan and Percheski 2008; Mokomane 2013).

In this revival of study on family in sub-Saharan Africa, stepfamily arrangements have been largely neglected (Frantz, Sixaba, and Smith 2015; Lawson et al. 2016). This is particularly surprising given the high level of fertility and remarriage in many countries across the subcontinent. At the time of union dissolution, more than $85 \%$ of women in sub-Saharan Africa will have at least one child under the age of 15 (Clark and BraunerOtto 2015), and various estimates show that more than 50\% of women enter into a new partnership within five years of their previous separation (Locoh and Thiriat 1995; Reniers 2003). It is inevitable that many of these children will also enter into a stepfamily arrangement as their mother begins a new relationship. Again, there is a limited body of literature on the consequences of a stepfamily arrangement on children's well-being (including schooling and health) in SSA. In a qualitative study conducted in Tanzania, Rwezaura (2000) reported various forms of abuse and discrimination against children living in a step-parent family arrangement. Various other claims about the abuse of stepchildren have been reported informally in SSA (Bowman and Brundige 2014), but without a clear quantitative analysis. One exception is the study by Lopus (2017) that used census data collected in 2009 and 2012 on Ibo Island in Mozambique to investigate educational participation as a reflection of childhood investments. The study assessed whether or not Mozambican children in all types of father-absent households received comparable educational investments, or if relatedness to children through blood or marriage dictated the level of investment in children's schooling. Lopus (2017) found that children in fatherpresent households generally attended school at the highest rates. In an unpublished study on father's absence by DeRose (2014), the author found that children who live with a stepfather have a lower chance of attending school than children who live with a single mother.

Our study therefore seeks to expand on the small number of research studies undertaken on this topic in SSA, with three main objectives. The first is to describe the prevalence of children living in stepfather family arrangements in 33 countries in SSA by analyzing the household roster and women's file data collected from recent demographic and health surveys. The second objective is to assess the effect of stepfather family arrangements on children's and adolescents' schooling in comparison to single-mother family arrangements and in comparison to families where both parents are living together. The final objective is to investigate how this relationship varies with children's age, gender, and place of residence. We focused only on the stepfather family arrangements in this study, in order to compare the results with children's outcomes from single-mother family arrangements, which have received much attention in recent studies. 


\section{Marriage, divorce, and remarriage in sub-Saharan Africa}

A number of studies on marriage and divorce in SSA have recently been conducted (Westoff 2003; Manda and Meyer 2005; Clark and Brauner-Otto 2015; Indongo and Pazvakawamba 2015; Hertrich 2017). Hertrich (2017) summarizes the evolution of nuptiality patterns in sub-Saharan Africa, revealing a generalized increase in the age at first marriage. Her conclusion is similar to those of Sayi (2015) and Garenne (2014), who observed the same pattern. However, Hertrich (2017) also notes that the increase in age at first marriage is not necessarily associated with a decline in fertility. It is unclear whether this age increase reflects a change in the norms surrounding marriage and fertility or a change in the marriage market, with increasing migration of young people, economic and political instability, and decreasing polygyny. Again, while the previous studies on marriage are conducted with a focus on fertility transition (Garenne 2014), they are silent about the institution of marriage itself. A quick assessment from the DHS data shows that a high proportion of women will marry at least once between the ages of 15 and 50 . With the notable exception of Namibia, where the proportion of never-married women aged 35-49 increased from 17\% in 1997 to $31 \%$ in 2013, and Gabon in 2012 (9\% single at ages 35-49), this proportion is less than 5\% in the rest of the countries in the study. Thus the marriage institution remains very present in African societies, just as it was in the past.

As with marriage, divorce is also very common in SSA. In one of the first studies on divorce in SSA (with a specific focus on West Africa), Locoh and Thiriat (1995) observed high rates of divorce in about half of the women in Togo's 1988 DHS who ended their first marriage by the age of 45 . Several other studies have provided estimates of the level of divorce in different parts of SSA. Reniers (2003) found that close to half of the marriages in three rural areas in Malawi ended in divorce within 20 years. Tilson and Larsen (2000) observed that only $60 \%$ of Ethiopian first marriages lasted more than 20 years. The study by Clark and Brauner-Otto (2015) presents a more thorough and broad investigation on divorce in sub-Saharan Africa. Using DHS data from 33 countries in SSA, the authors show that divorce in some countries is relatively stable, while data from 20 other SSA countries point to a declining trend. In contrast to what previous theories predicted (Goode 1993), divorce is not increasing with growing urbanization in SSA. It is safe to say, however, that the level of divorce in SSA is already high for its stage in the demographic transition.

While research on marriage and divorce has been widely studied, very few studies have been undertaken on remarriage in SSA. A recent collection of studies on separation, divorce, repartnering, and remarriage around the world did not produce any research on repartnering and remarriage in sub-Saharan Africa (Cherlin 2017). This suggests that research in this area has been lacking in SSA. Reference to some earlier studies is therefore required to give some context on remarriage in SSA. The study by Locoh and Thiriat 
(1995), for example, estimated the rate of remarriage in the country of Togo and found that more than $67 \%$ of the women remarried within three years of their divorce or separation. The authors also highlight that the rate of remarriage is higher after separation than in the case of widowhood, but it is lower among educated women. However, no information is provided about stepfamilies in the country. As with Togo, remarriage is also very high in Malawi, where Reniers (2003) showed that $40 \%$ of women remarry within two years of divorce. This proportion reaches $70 \%$ after five years and $90 \%$ after 10 years. The study by de Walque and Kline (2012) found that in nine of the 13 countries studied in sub-Saharan Africa, remarried women made up $15 \%$ of married women as a whole. In addition, a recent study by John (2018) using novel demographic estimate approaches found that in Malawi, the probability of experiencing first-union dissolution within 15 years dropped from $45.9 \%$ to $40.0 \%$ between 1992 and 2015, while the comparable likelihood of remarriage decreased from $36.1 \%$ to $27.7 \%$ over the same period.

\section{Stepfamily arrangements and children's schooling in SSA: Theoretical frameworks}

In developed countries, where there is extensive literature about the stepfamily, it was shown that this type of family arrangement is disruptive and has detrimental consequences for young adults, adolescents, and children, especially in terms of schooling, health, and harmful behaviours (Amato 2001; Case, Lin, and McLanahan 2001; Dawson 1991; Heckman 2011). The stress-related model, the stepfather involvement model, and other theories have emerged to explain these negative outcomes (Dunn 2002; Ribar 2004; Saint-Jacques et al. 2018; Sweeney 2007) and have focused on the premise that children are more likely to have better resources when they live with both biological parents (Coleman, Ganong, and Fine 2000; Heckman 2011). According to the stress-related model, parental remarriage is accompanied by stress for both the parents and children, which may negatively impact their lives. These stresses are brought on by many changes and instabilities during the process of remarriage: a new residence with new household members, a new place with new friends to make, and, for the child, adapting to a stepparent (Coleman, Ganong, and Fine 2000; Crosnoe and Cavanagh 2010; Goldberg 2013). Another stress factor is related to the pre-remarriage environment, where conflict is common before divorce and the parent may have numerous partnerships before their eventual remarriage (Osborne and McLanahan 2007). These effects are cumulative and can negatively impact the children when they enter a step-parent's household. Finally, the stress model points out the resource deprivation faced by children in stepfamilies compared to children who live with both their biological parents.

The stepfather involvement model, for its part, describes differences in parenting between parents and step-parents. The theory explains the negative consequences of step- 
parents on children's well-being with the fact that step-parents are less committed to their stepchildren and have reduced positive interactions with them (Coleman, Ganong, and Fine 2000; Ribar 2004). Not only is the stepfather less involved, but the mother's involvement is also reduced. This, it is argued, arises because the mothers must commit themselves to their new partners, which lowers their interactions with their biological children. This suggests that time management in a stepfamily is more conflicting than that observed in families with both biological parents and in families where the mother is the sole provider of support (Case, Lin, and McLanahan 2001).

The stress-related and the step-parent involvement models have been successfully tested in various studies in developed countries (Coleman, Ganong, and Fine 2000). However, in the context of SSA, parental nonresidence or parental absence in a family is not uniformly detrimental to children (DeRose 2014; Gaydosh 2017). To better understand how these theories play out in an African context, which is characterized by a larger and more heterogeneous family structure, parental absence in a family is discussed in a general framework of the power relationships within the household; this, it is argued, affects the way in which children are raised and how resources are allocated to them (Adjiwanou and LeGrand 2014; Blumberg 1984; Cubbins 1991; Folbre 2008; Quisumbing 2003; Thomas 1990).

\subsection{Power relationships within the household}

Although SSA is diverse in terms of sociocultural norms and practices, it is commonly accepted that this context is segregated in terms of gender roles and that they are unequal for women, particularly married women (Adjiwanou and LeGrand 2014; Gaydosh 2017; Kabeer 2016; Ohenaba-Sakyi and Takyi 2006). Various aspects of gender inequality have been reported in the literature; they include the practice of purdah, or seclusion, which limits women's interaction with others or their mobility outside the household (Kritz and Makinwa-Adebusoye 1999), as well as the multiple domestic duties that society expects from women (Amoakohene 2004). These and similar inequalities are found throughout SSA countries. They are reproduced informally with the aim of maintaining male dominance and are thought to be prejudicial to women's status by limiting their access to information and health services. They also further increase women's vulnerability to gender-based violence (Dodoo and Frost 2008; Blanc 2001; Desai and Andrist 2010; Heise 1998; Stephenson and Elfstrom 2012). This power asymmetry within the household generally prejudices children's well-being (Luz and Agadjanian 2015).

Nevertheless, there is one aspect (divorce) where the dominance of male power in a family relationship is weakened. Divorced women, as well as remarried women, tend to experience greater empowerment than women in their first marriage (Allen et al. 2001; Antoine and Marcoux 2014; Dial 2008; Sweeney 2010), and this could be beneficial to 
their children. Coleman, Ganong, and Fine (2000) have suggested five reasons to explain why women are more empowered in subsequent marriages relative to their first.The first three reasons are (1) women's personal experiences from their previous marriages and their desire to maintain the same authority gained after divorce; (2) the greater resources women often bring to new marriages; and (3) the decision to remarry, which is often agentic. The fourth and fifth reasons are related to the behaviour of the new partner, who may not only have different ideas about marital roles but may also be more willing to concede during marital conflicts. Despite this, Locoh and Thiriat (1995) caution that in the case of SSA, while divorce does bring some empowerment from the partner, it does not necessarily empower a woman vis-à-vis her family of origin. Remarriage may sometimes come with uncertainties about income, which might limit women's bargaining ability. For Locoh and Thiriat (1995: 88), "such unions (remarriage) have a positive side, that of women's autonomy and a more negative side, that of the economic precariousness that they are likely to generate."

\subsection{The model of child-rearing in SSA}

While the stress-related model and the stepfather involvement model may also explain the expected negative effect of stepfather family arrangements on children's well-being in SSA, especially when the mother enters a polygamous relationship (Bove and Valeggia 2009), the specificity of SSA's context with regard to gender roles may decrease this negative effect. Indeed, the environment within which children are raised in SSA is typically highly gender-stratified; the father is the breadwinner and the mother is the "nurturing" face (Fouts and Brookshire 2009; Whyte and Whyte 2011). This has three main consequences. First, the emotional ties between fathers and their children are usually lower compared to what is observed in developed countries (Tsala Dimbuene and Kuate Defo 2013). Second, the paternal role is mainly to meet the subsistence needs of the family - something that other family members can provide, including the stepfathers. Finally, the relationship within stepfamilies may be less conflictual in SSA. Both historically and currently, and especially in rural areas, children have been "raised" by the community (Cebotari and Mazzucato 2016; Goody 1982). According to Clark et al. (2017), African families are depicted as maintaining large kinship networks of close reciprocal bonds among members, which continue today as a result of the level of poverty and the absence of public safety nets. In their study on single mothers, they show how various family members, including uncles and aunts, are called upon to provide support to single mothers and their children in an urban slum of Nairobi (Clark et al. 2017). This is reflective of Pryor's (2012) assertion that in some African cultures, social parenting is common and that the concept of a nuclear family raising children is not the norm. He concluded that the idea of stepfamilies is also less common in these cultures; stepfamilies exist but their 
significance is different. Therefore, the attachment to biological parents is weaker than in developed countries. Lloyd and Blanc (1996) reported this same conclusion in their study of extended families in SSA. Although the reality may be somewhat different today, many families in SSA continue to raise their children following this norm.

\subsection{Resource allocation within the household}

Folbre (2008) has described the model of resource allocation for children, highlighting the importance of the parents in providing care and allocating resources to their children, but Folbre also outlines the role of the state in providing resources. In SSA, the responsibility parents have for their children can be seen as an obligation, but also as an investment given the expected returns from their children when they become older. In the absence of social protection, adult children remain the main providers of resources and support for their parents. The support provided to the children is not neutral and is optimal when parents rear their children together (Caldwell 1976, 2005).

Since there are no norms or obligations that compel stepchildren to support their stepfather later in life, as is the case with biological parents, this may explain why the stepfather might invest less in his stepchildren (LeVine and LeVine 1981; Rwezaura 2000). As a stepfather may not expect anything from his stepchildren, he may then advantage his own children or himself instead of his stepchildren. This is further supported by the kin selection theory, which postulates that the investment in children is higher based on the closeness of the person to the children (for instance, from biological father to uncle to stepfather) (Lopus 2017; Case, Paxson, and Ableidinger 2004). Furthermore, resource allocation within the household is not always optimal, since the (step)father and mother may have divergent priorities. Another factor within resource allocation arises from a study by Thomas (1990), who has shown that mothers are more willing to invest more in their daughters and fathers in their sons.

Resource allocation in a stepfamily household is further complicated by the diversity of children in this typical family arrangement and the increasing cost of child-rearing in SSA (Gage 1997; Rwezaura 2000). As pointed out by Dunn (2002), stepfamilies encompass a wide variety of forms and situations - from simple to more complex, with varying consequences on children. Arising from the high levels of polygyny in some parts of SSA (Bove and Valeggia 2009), many divorced women will enter a new relationship with a married partner (Antoine and Marcoux 2014; Antoine and Nanitelamio 1996), and they are more likely to remarry an older partner who has children from previous marriages (Reniers 2003; Barbieri and Hertrich 2005). This may dilute the resources that would otherwise be available to the stepchildren. Indeed, when their mothers enter a polygynous remarriage arrangement, children are competing with both their mothers' newborn children and the children of their stepfathers' co-wives; this may affect their well-being 
and survival. For instance, a study by Omariba and Boyle (2007) using data from 22 SSA countries for the period 1990 to 2002 found that children in polygynous families are $22 \%$ more likely to die compared to children in monogamous families. Alternatively, the competition based on fertility that results from polygynous households could also reduce the investment in children's well-being (Rossi 2018).

\subsection{Moderating effects}

Finally, the effect of family structure on children's well-being may also depend on various moderating factors, such as age, gender, and place of residence. Various research in developed countries and especially in the United States has demonstrated that boys are more negatively affected in a stepfamily arrangement than are girls (Raley and Sweeney 2020; Osborne and McLanahan 2007). Most of these studies have focused on children's psychological well-being. We expect that the effect may be different in the case of schooling in SSA. Indeed, in the SSA context, various studies have found that boys are well catered to and have a higher probability of succeeding at school compared to girls (Roby, Erickson, and Nagaishi 2016). One could expect that female children living in a stepfather family arrangement will similarly be discriminated against (Thomas 1990; Cubbins 1991; Townsend et al. 2002).

The importance of the place of residence in shaping various demographics phenomena is well established (Diez Roux 2001; Montgomery and Hewett 2005). This is demonstrated, for example, by the theory of social capital, which reveals the importance of connections and resources within the community for the well-being of children (Coleman 1988). According to this theory, the remarriage of the mother can distance her and her children from their usual resources, a social mobility that can be greater in urban areas than in rural areas. Thus urban areas isolate more women from the resources that the extended family and community in rural areas could provide to the children in unstable families (stepfamily or single-motherhood arrangement). For instance, Clark et al. (2017) found in their study in Kenya that around one-third of the single women they studied did not receive any financial help or assistance for their child care. At the same time, urban areas in SSA encompass many resources to support children's schooling, in a way that alleviates any situation in which children may find themselves. As evidenced by the UNESCO's reports on education, primary and secondary level school attendances are very high in urban areas compared to rural areas. In addition, urban residency may provide more empowerment to women to mitigate any adverse effects due to remarriage. Finally, the child's age can be a determining factor. Conflicts with stepfathers can arise more often among older children than younger ones, as shown by several studies in developed countries (Ganong, Coleman and Jamison 2011; Raley and Sweeney 2020). These tensions can negatively affect children's schooling further. 


\subsection{Hypotheses}

The way in which stepfathers can affect children's schooling is complex. Various mechanisms and counter-mechanisms are involved, and they differ from one context to another. Based on this, we formulated four hypotheses for this study:

Hypothesis 1: Children living with their two biological parents have a greater chance of attending school compared to children living with a stepfather (emotional and resources effects).

Hypothesis 2: Children living with a stepfather have a greater chance of attending school compared to children living with a single mother (resources effect).

Hypothesis 3: In the case of Hypothesis 1 and Hypothesis 2, the effect will be different for boys and girls (gender effect). As related to Hypothesis 1, we postulated that girls have a greater chance of school dropout compared to boys in stepfamily arrangements than in families with both biological parents. Again in regard to Hypothesis 2, we postulated that girls have a greater chance to remain in school compared to boys in stepfamily arrangements than in a single-mother family. Clearly, this hypothesis means that if there is a gap in school attendance between girls and boys (with girls being more disadvantaged), this gap will be higher in a stepfather family than in a biological family with both parents, while it will be lower in comparison to a single-mother family.

Hypothesis 4: The effects postulated in Hypothesis 1 and Hypothesis 2 are stronger in urban areas than in rural areas owing to the lowering (eroding) of kinship in urban areas. Clearly, we hypothesized that the negative effect of stepfather family arrangements on children's schooling (in comparison to children who live with their two biological parents) will be stronger in urban areas compared to rural areas.

\section{Data and methods}

\subsection{Problems of selection}

The results regarding the effect of the stepfather family arrangement on children's wellbeing may be compromised by methodological issues related to selection bias (Coleman, Ganong, and Fine 2000; Sweeney 2007). Selection bias occurs when the researchers cannot attribute a specific cause to one variable and when unobserved variables could explain the results. For instance, observed negative outcomes for the children in a stepfather family may precede the remarriage of their mother to the stepfather, and therefore they cannot be attributed to the stepfamily. Indeed, given that divorce negatively affects a 
child's health and well-being (Chae 2016; Thiombiano, LeGrand, and Kobiané 2013), it is difficult to ascribe these effects to stepfamilies if the situation endures over time. While problems of selection bias may fairly be addressed using longitudinal data, the crosssectional data used in this study require some methodological caution to avoid selection bias (Adjiwanou and Legrand 2013). In the present study, this problem was circumvented by focusing on an outcome that is susceptible to change over time. Nonetheless, other forms of selection, such as measurement errors, reverse causation, and omitted variables, may still affect the interpretation of the results (Adjiwanou and Legrand 2013; Ribar 2004).

Selection bias also takes different forms in SSA. Two types of selection are especially pertinent: selection into remarriage and selection into a stepfamily. The crucial distinction is that marriage is close to universal, while remarriage is not and is a choice made by women based on their expectation about what the remarriage will bring to them or to their children (Reniers 2003). For instance, it has been reported that educated women wait longer before remarrying compared to uneducated women (Locoh and Thiriat 1995). Again, the decision to remarry can be dictated by the specific situation of the children, such as difficulties at school, poverty, or the need to bring a "paternal figure" into the home, which may motivate a mother to remarry. In this case, it is the children's well-being that affects the type of family and not the other way around (Ribar 2004).

With regard to selection into a stepfamily, fostering often supersedes the role of the parents (Isiugo-Abanihe 1985). Unlike in developed countries, a significant proportion of children in SSA are fostered out to other families, sometimes in order to allow their mother to remarry (Grant and Yeatman 2014). This is one aspect of what Isiugo-Abanihe (1985) coined "crisis fostering." In this situation, if the children who remain with their remarried mother have different characteristics than those who were fostered, conclusions regarding the impact of the stepfamily's arrangement on children's well-being are biased. It is probable that children who are fostered are older and healthier than those who remain with their mothers, giving rise to selection bias at the child level. However, in many SSA countries, social norms prevent remarrying mothers from bringing their biological children into a new relationship. As a consequence, the selection of the children into the stepfamily depends less on the children's own characteristics and more on social norms in the area. The modelling approach to address the selection bias in this study involves controlling for unobserved heterogeneity at the community level. However, a sensitivity analysis was conducted to examine the effect of an alternative approach (predicated on selection at the mother level). 


\subsection{Data}

This study used the most recent Demographic and Health Survey data from 33 SSA countries collected from 2006 to 2015 . The DHS applied multistage stratified, probabilitybased sampling to provide national as well as rural/urban-representative samples of women of reproductive age. At the first stage, a random sample of clusters (primary sampling unit - PSU) was selected. For instance, in Ghana in 2014, 427 clusters were selected, 216 in urban areas and 211 in rural areas. At the second stage, a systematic sampling of households was selected in each cluster (approximately 30 in Ghana in 2014).

The DHS surveys used standardized questionnaires that allowed for a comparison of results across countries and collected data on various dimensions of household composition and characteristics, women's behaviour, and children's health (Short Fabic, Choi, and Bird 2012). This study used information from two databases of this survey: the Household Roster, which lists all members of the household, the survival statuses and presence of parents in the household, and information on schooling for children aged 617 years; and the Women Recode File, which lists information on the women, especially their marital status and their children under age 5. The unit of analysis of this study was children linked to women and household characteristics. Over the survey cycles, new topics have emerged, along with increased sample sizes. For the recent DHS surveys, the initial sample of children aged 0-5 ranged from 3,136 in Swaziland to 30,086 in Nigeria, while the sample for children aged 6-17 ranged from 8,054 in Swaziland to 60,360 in Nigeria. Overall, the sample for the most recent surveys comprised 1,153,348 children aged $0-17$ years. We limit the analysis to children aged $0-14$ years, because most $15-$ to 17-year-olds are fostered out or have started their own families (Schrijner and Smits 2018).

We used the complete data sets on children aged 0 to 14 to describe the family structure under which they lived in SSA (Objective 1). For the explanatory analysis (Objectives 2 and 3), given that the analysis controls for characteristics of the child's mother, children whose mothers are not co-resident are excluded from the analysis limiting the sample to only children living in a stepfather family arrangement, with both biological parents, or with a single mother. This gives us a total analytical sample of 277,726 children aged $6-14$.

\subsection{Operationalization of the stepfather family arrangement}

In this study, the main independent variable of interest is the stepfather family arrangement. Information from the household questionnaire and the Women Recode File were combined to identify different family structures and particularly the stepfather family arrangements (see Figure 1). For children under 17 years of age, the household questionnaire collected information about the survivorship and co-residence (if alive) of their 
biological parents. According to this information, four initial family structures were identified: 1) presence of both biological parents in the household; 2) no biological parents in the household (i.e., the child is fostered out); 3) presence of only a biological father; and 4) presence of only a biological mother. Children who lived with their biological mothers but not with their biological fathers were further classified into: (a) living with a single mother; (b) living with a stepfather; or (c) living in an indeterminate family situation. To distinguish between these three groups, information on the marital status of the mothers and the presence of their partners in the household was needed. This information was available in the Women Recode File. Situation (c) arises where the child's mother is not interviewed during the survey (i.e., she is not in the Women Recode File) and where the child's mother is married but does not live in the same household as her partner. In this last case, it was uncertain if the partner was the father of the child or the stepfather. Situation (c) also included all children whose mother's marital status was unknown. We note that there was no need to merge the two files (household record file and individual file) to define single motherhood. In the most recent DHS surveys, a direct question on marital status was addressed to all household members aged 15 and older. This is the question used to define single motherhood in this study.

\section{Figure 1: Tree diagram for the identification of stepfather family arrangement from DHS data}

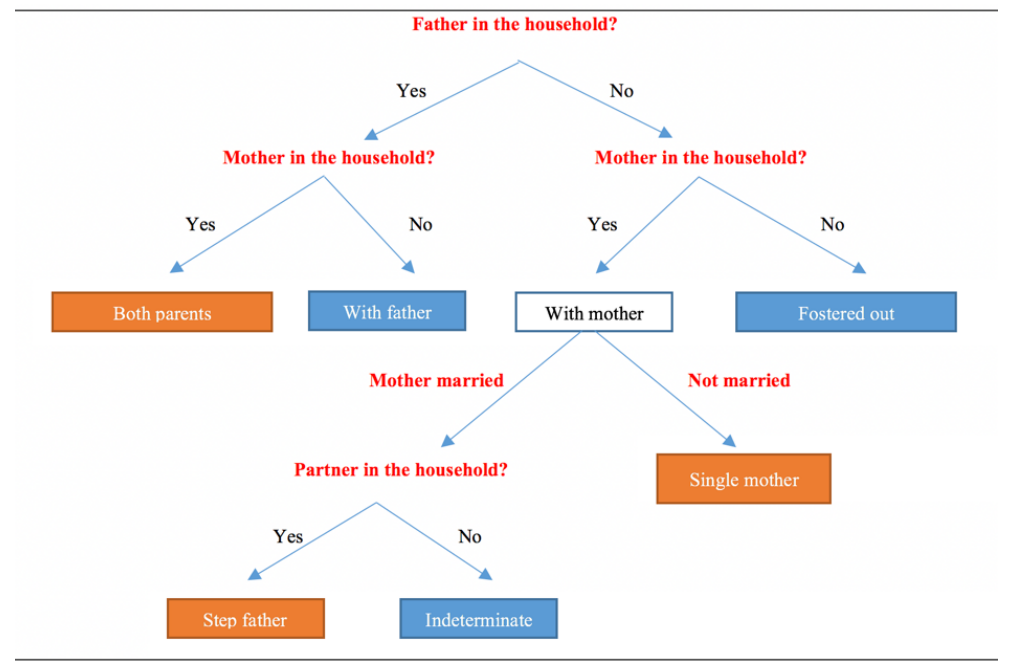

Note: The shaded categories are used in this study. The orange boxes are the categories for the regression models.

Because the unit of analysis was the child, living with both parents did not imply that 
the two parents were in their first marriage; it could be a "blended" family. Furthermore, although the family structure was measured at the child level, it was necessary to correct for inconsistencies based on the information provided by siblings. For instance, a child who was first found to be living in a single-mother household was changed to be living in a stepfather family if the mother had another child whose father was in the household. Cross-checking the information of children from the same mothers provided insight for these corrections. Finally, the quality of the family structure variable depends on the accuracy of reporting of marriage - when the data were merged, the information provided by the interviewed (mother) on her marital status was preferred over the information provided by the household respondent.

\subsection{The dependent variable}

The dependent variable was the school attendance of children (aged 6-9 and 10-14) at the time of the survey. This variable was coded 1 if a child was at school at the time of the survey and 0 otherwise. This variable was chosen because it was susceptible to change over time. Since the data comprised current information (at the time of interview) and not information from prior points in time, a further assumption was made: adverse outcomes that may have existed when a child's mother was divorced may have been mitigated when the child's mother remarried.

\subsection{Statistical analysis}

Various approaches have been used to deal with the problem of selection bias (Ribar 2004). In this study, a cluster-level fixed effect model was used to control for unobserved heterogeneity that could explain any observed relationship between family arrangement and children's well-being (Allison 2009). The model is expressed as follows:

$\mathrm{Y}_{i j}=\beta S_{i j}+\alpha X_{i j}+\delta_{j}+\epsilon_{i j}$,

where $Y_{i j}$ is a dummy variable indicating whether children aged 6-14 were attending school at the time of the interview; $S_{i j}$ is the type of family structure under which the child $i$ of cluster $j$ lives; $X_{i j}$ represents a vector of independent variables; $\delta_{j}$ is a vector of unobserved fixed factors for cluster $j$; and $\epsilon_{i j}$ is a random and normally distributed error terms.

Three models were estimated. Model 1 assesses the effect of family structure on children's schooling, controlling for children, mother, and household characteristics. Model 
2 assesses the interaction effect between stepfather family arrangement and the children's sex, in order to assess any discriminatory effects against girls. The margins and marginsplot commands were used to test the significance of the interaction effect (Buis 2010; Williams 2012). Finally, Model 1 is reestimated separately for urban and rural place of residence of the children to understand how the context affects the previous results (Model 3).

In each model, we controlled for several independent variables as demonstrated in previous studies. These variables were at the child level, the child's sex and age. At the women/household level, wealth index (lowest, lower, middle, higher, highest), mother's level of education (none, primary, secondary and higher), mother's age (under 25, 25-34, $35-49,50$, and older), and the number of children under 5 years of age in the household were included. Finally, all analyses were run for both the pooled data set of all countries and for each country separately. The univariate and bivariate tables at country level were weighted with the women's sample weight variable, whereas for the pooled data sets, a new weighting variable was computed. It considered the population size of each country at the time of the survey (tables available on request).

\subsection{Sensitivity analysis}

Finally, a sensitivity analysis using the mother's level fixed effect (unobserved mother and cluster characteristics) was used to test for possible biases in our previous findings (Case, Lin, and McLanahan 2001; Ermisch and Francesconi 2001; Hao and Matsueda 2006). Because this analysis uses "within mother differences", it was only run on the subsample where at least two children live with their mother, with different family arrangements. Thus the analysis was limited to children living with mothers who are remarried and have at least one child from a previous partnership or who have nonmarital births but have at least one child from a current marriage. In addition, this analysis involved children who were in the same age groups. By limiting the sample to this group, the sensitivity analysis ignored the large majority of children in the sample who live in stable-intact or non-intact families (Ribar 2004).

\section{Results}

\subsection{School attendance by age in SSA}

Figure 2 presents the weighted proportion of children at school at the time of the survey in each country. Overall, the proportion is $74 \%$ for the age group $6-9$ years and $78 \%$ for the age group 10-14 years. At the country level, the proportion of children attending school is lower in Niger (50\% and 42\%, respectively, for the two age groups) and Burkina Faso 
(50\% for both age groups) and highest (above 90\%) in Congo, Gabon, Kenya, Lesotho, Namibia, Swaziland, Uganda, and Zimbabwe.

Figure 2: Weighted proportion of children at school by age groups, 33 DHS's in SSA, 2006-2015

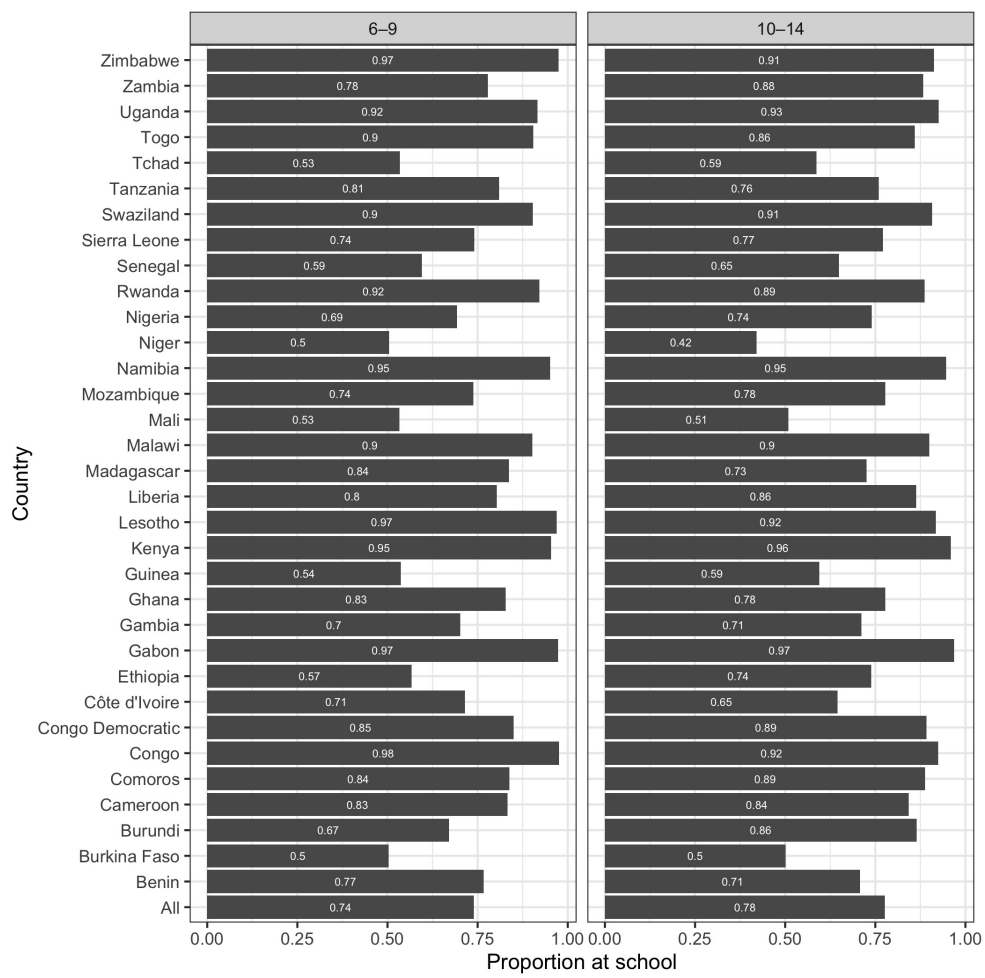

\subsection{Family structure arrangement in SSA}

Figure 3 shows the different family structures in which children live, with children most likely to live with both of their biological parents in Burkina Faso and Mali, and less likely to live in this family arrangement in Swaziland, Namibia, Lesotho, and Gabon. In addition, this figure shows that two-thirds of the countries studied had a proportion of children in the stepfather family arrangement, which was above the overall mean of $2.5 \%$, with the highest proportion found in Gabon, Comoros, and Mozambique. Overall, 
most children $(65.2 \%)$ were living with both of their parents, $2.5 \%$ were living with a stepfather family arrangement, $8.2 \%$ were living with a single mother, $6.2 \%$ were living in a family where the mother was married but the children's father was not living in the household (nonresidential [step]fathers), $4.7 \%$ were living with their father, and $13.2 \%$ were fostered out (Figure 7.1, appendix). Furthermore, the majority of the younger children $(73.7 \%)$ were living with both of their parents, which was proportionally greater than most $(56.9 \%)$ of the older children. Finally, older children $(21.5 \%)$ were more likely to be fostered than younger children (6.5\%) (Figure 7.1, appendix). Supplementary tables present the cross-tabulation of the family arrangement variable and various variables of the study (child's age and sex, school attendance, and mother's level of education).

Figure 4 presents the same results by the children's age groups. It shows that as the children aged, they were less likely to live with both their biological parents. At the ages of 10-14, the proportion of children living with both their biological parents ranges from $20 \%$ in Swaziland to $74 \%$ in Mali. This proportion is under 50\% in 19 of the 33 countries in the study. In comparison, for the children aged 0-4, it is only in Swaziland, Namibia, Lesotho, and Gabon that less than 50\% of the children lived with their two biological parents.

\subsection{Effect of stepfather family arrangement on children's schooling}

Table 1 presents the parameter estimates (odds ratios) of the effect of a stepfather family arrangement and a single-motherhood arrangement (in comparison to living with both biological parents) on children's schooling for children aged 6-9 (columns 2 and 3), for children aged 10-14 (columns 5 and 6), and for all age groups (columns 8 and 9) in the full model. Overall, the results show that children aged 6-9 living in a stepfather family arrangement were $18 \%$ less likely to attend school compared to children living with both biological parents. This was also observed in many countries, with the highest negative effects including Swaziland ( $\mathrm{OR}=0.26)$, Rwanda $(\mathrm{OR}=0.41)$, and Gabon $(\mathrm{OR}=0.41)$ (see Table 1). 
Figure 3: Weighted proportion of children aged 0-14 by family structure and age group, 33 DHS's in SSA, 2006-2015

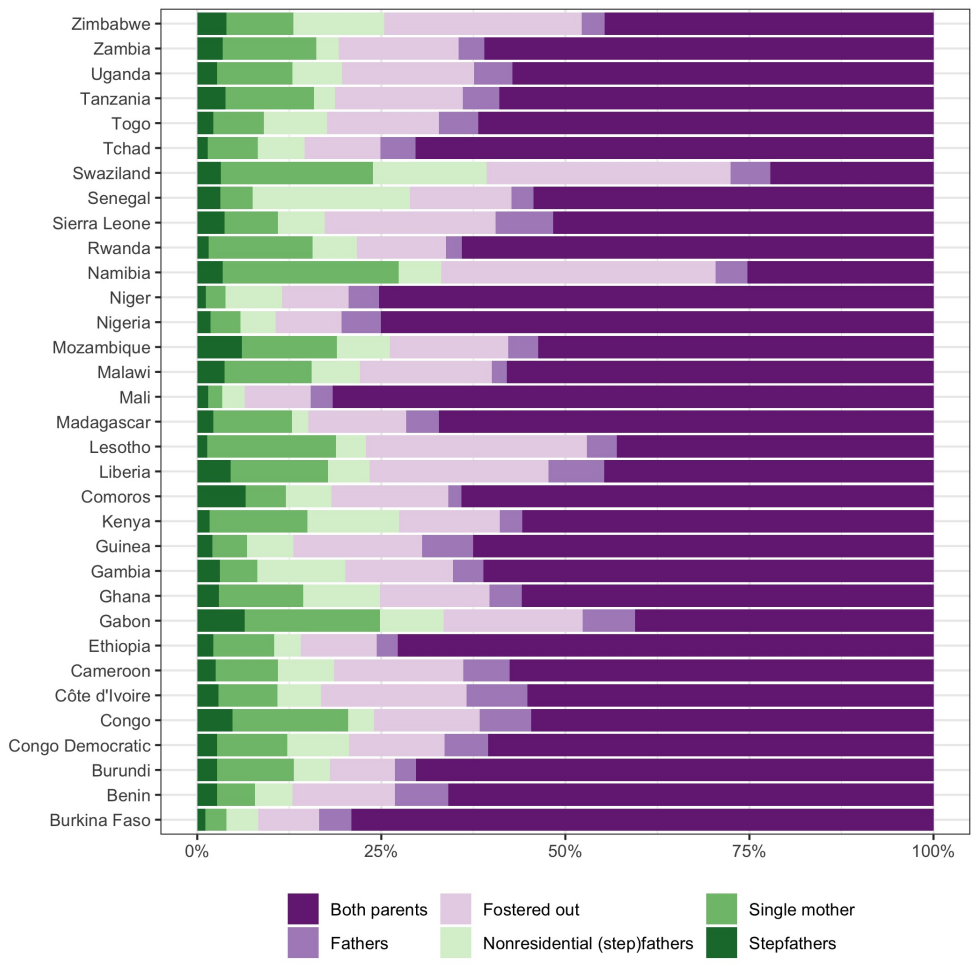


Figure 4: Weighted proportion of children in each country by age and family structure, 33 most recent DHS's in SSA

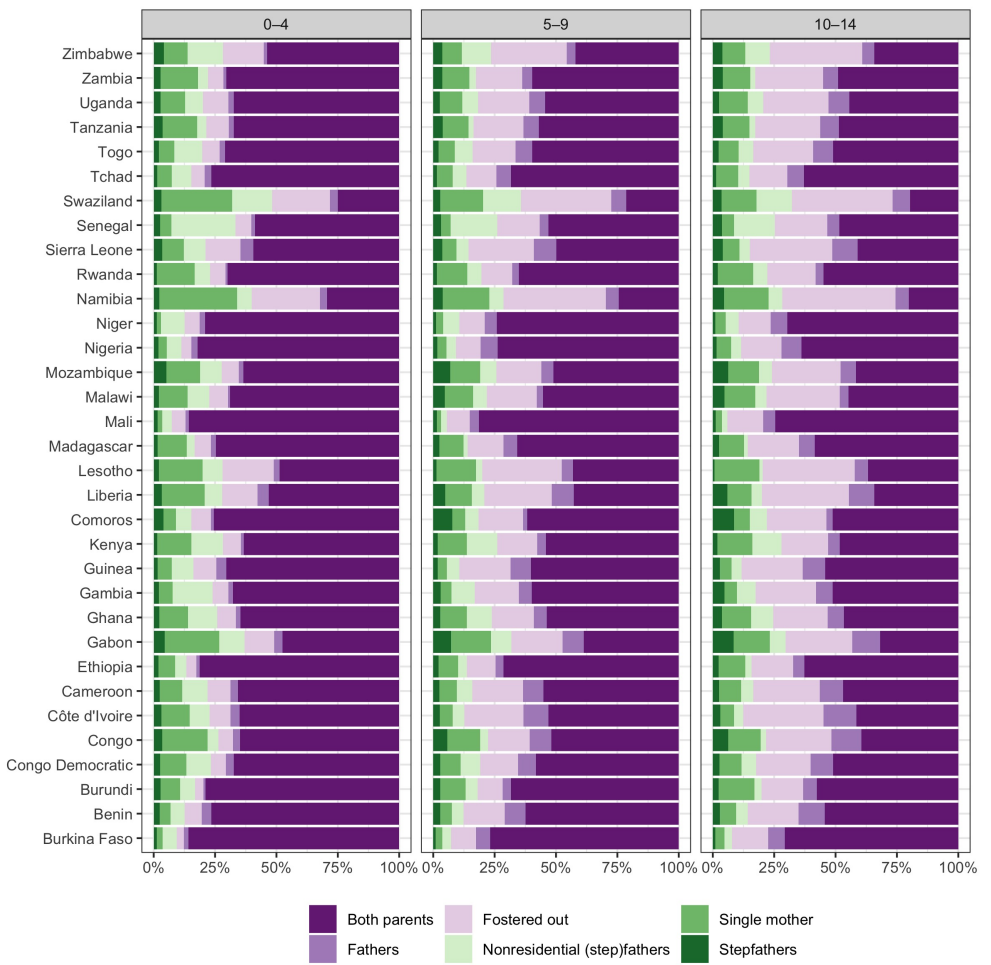

For children aged 10-14, the effect of living in a stepfather family arrangement was even worse with regard to their school attendance. Overall, there was a $32 \%$ lower chance of attending school among those age 10-14 living in a stepfather family arrangement as compared to children of the same age who were living with both of their biological parents. This negative effect was also observed in many other countries, as shown in Table 1. When comparing children living in a single-motherhood family arrangement to those living with both biological parents, results show that children in a single-motherhood family were $16 \%$ less likely to attend school compared to children living with both biological parents; furthermore, school attendance was $13 \%$ less likely in the age group 6-9 compared to $23 \%$ in the age group 10-14. This negative effect was observed in approximately half of the countries studied. 
Adjiwanou, Boco \& Yaya: Stepfather families and children's schooling in sub-Saharan Africa

Table 1: Cluster-level fixed effect logistic regression analysis showing odds ratios of children's school attendance by family arrangement and children's age in 33 SSA countries; reference category is both biological parents

\begin{tabular}{|c|c|c|c|c|c|c|c|c|c|c|c|c|}
\hline \multirow{3}{*}{ Country } & \multicolumn{4}{|c|}{$6-9$ years } & \multicolumn{4}{|c|}{$10-14$ years } & \multicolumn{4}{|c|}{$6-14$ years } \\
\hline & \multicolumn{2}{|c|}{ Stepfather } & \multicolumn{2}{|c|}{$\begin{array}{l}\text { Single } \\
\text { motherhood }\end{array}$} & \multicolumn{2}{|c|}{ Stepfather } & \multicolumn{2}{|c|}{ Single motherhood } & \multicolumn{2}{|c|}{ Stepfather } & \multicolumn{2}{|c|}{$\begin{array}{l}\text { Single } \\
\text { motherhood }\end{array}$} \\
\hline & OR & se & OR & se & OR & se & OR & se & OR & se & OR & se \\
\hline All & 0.817 & (0.03) & 0.872 & $(0.02)$ & 0.681 & $(0.03)$ & 0.772 & $(0.02)$ & 0.761 & $(0.02)$ & 0.844 & $(0.02)$ \\
\hline Burkina Faso & 0.931 & $(0.25)$ & 0.724 & $(0.13)$ & 1.100 & $(0.28)$ & 0.797 & $(0.14)$ & 0.969 & $(0.18)$ & 0.763 & $(0.09)$ \\
\hline Benin & 0.700 & $(0.12)$ & 0.822 & $(0.14)$ & 0.514 & $(0.09)$ & 0.924 & $(0.16)$ & 0.605 & $(0.07)$ & 0.837 & $(0.10)$ \\
\hline Burundi & 1.055 & $(0.27)$ & 0.812 & $(0.13)$ & 0.396 & $(0.12)$ & 0.834 & $(0.17)$ & 0.743 & $(0.14)$ & 0.823 & $(0.10)$ \\
\hline Congo Democratic & 0.639 & $(0.09)$ & 0.698 & $(0.07)$ & 0.647 & $(0.14)$ & 0.602 & $(0.09)$ & 0.635 & $(0.07)$ & 0.662 & $(0.05)$ \\
\hline Congo & 0.668 & $(0.18)$ & 0.750 & $(0.16)$ & 0.771 & $(0.25)$ & 0.546 & $(0.13)$ & 0.718 & $(0.14)$ & 0.629 & $(0.10)$ \\
\hline Côte d'Ivoire & 0.639 & $(0.14)$ & 0.602 & $(0.11)$ & 0.563 & $(0.13)$ & 0.686 & $(0.14)$ & 0.579 & $(0.09)$ & 0.629 & $(0.08)$ \\
\hline Cameroon & 0.719 & $(0.19)$ & 1.055 & $(0.23)$ & 0.740 & $(0.25)$ & 0.717 & $(0.18)$ & 0.692 & $(0.13)$ & 0.880 & $(0.14)$ \\
\hline Ethiopia & 0.643 & $(0.13)$ & 0.839 & $(0.09)$ & 0.674 & $(0.13)$ & 0.713 & $(0.09)$ & 0.663 & $(0.09)$ & 0.796 & $(0.06)$ \\
\hline Gabon & 0.415 & $(0.12)$ & 0.623 & $(0.18)$ & 0.584 & $(0.29)$ & 0.901 & $(0.46)$ & 0.507 & $(0.11)$ & 0.707 & $(0.16)$ \\
\hline Ghana & 0.720 & $(0.30)$ & 0.577 & $(0.16)$ & NC & NC & NC & NC & 0.637 & $(0.16)$ & 0.512 & $(0.09)$ \\
\hline Gambia & 1.036 & $(0.24)$ & 1.022 & $(0.21)$ & 0.532 & $(0.12)$ & 1.582 & $(0.46)$ & 0.785 & $(0.12)$ & 1.202 & $(0.20)$ \\
\hline Guinea & 1.173 & $(0.31)$ & 0.542 & $(0.12)$ & 0.399 & $(0.09)$ & 0.626 & $(0.15)$ & 0.598 & $(0.10)$ & 0.611 & $(0.10)$ \\
\hline Kenya & 1.444 & $(0.37)$ & 1.090 & $(0.17)$ & 1.127 & $(0.29)$ & 0.844 & $(0.16)$ & 1.253 & $(0.21)$ & 1.012 & $(0.12)$ \\
\hline Comoros & 0.633 & $(0.16)$ & 0.500 & $(0.16)$ & 1.085 & $(0.40)$ & 0.316 & $(0.12)$ & 0.729 & $(0.14)$ & 0.445 & $(0.10)$ \\
\hline Liberia & 1.011 & $(0.19)$ & 0.668 & $(0.10)$ & 0.673 & $(0.17)$ & 1.015 & $(0.23)$ & 0.851 & $(0.12)$ & 0.755 & $(0.09)$ \\
\hline Lesotho & 0.206 & $(0.22)$ & 0.614 & $(0.20)$ & 0.178 & $(0.21)$ & 0.742 & $(0.30)$ & 0.256 & $(0.17)$ & 0.702 & $(0.16)$ \\
\hline Madagascar & 0.543 & $(0.09)$ & 0.717 & $(0.07)$ & 0.455 & $(0.08)$ & 0.524 & $(0.06)$ & 0.529 & $(0.06)$ & 0.622 & $(0.04)$ \\
\hline Mali & 1.036 & $(0.26)$ & 0.584 & $(0.17)$ & 0.599 & $(0.18)$ & 1.250 & $(0.38)$ & 0.852 & $(0.16)$ & 0.824 & $(0.17)$ \\
\hline Malawi & 0.868 & $(0.11)$ & 0.910 & $(0.08)$ & 0.404 & $(0.07)$ & 0.651 & $(0.10)$ & 0.637 & $(0.06)$ & 0.834 & $(0.06)$ \\
\hline Mozambique & 0.689 & $(0.09)$ & 0.864 & $(0.10)$ & 0.656 & $(0.10)$ & 0.632 & $(0.09)$ & 0.666 & $(0.06)$ & 0.744 & $(0.06)$ \\
\hline Nigeria & 0.923 & $(0.17)$ & 1.031 & $(0.16)$ & 1.148 & $(0.27)$ & 0.800 & $(0.15)$ & 1.020 & $(0.14)$ & 0.953 & $(0.11)$ \\
\hline Niger & 0.673 & $(0.18)$ & 0.909 & $(0.17)$ & 0.847 & $(0.21)$ & 0.950 & $(0.20)$ & 0.770 & $(0.13)$ & 0.906 & $(0.12)$ \\
\hline Namibia & 2.155 & $(0.92)$ & 1.477 & $(0.42)$ & NC & NC & NC & NC & 1.802 & $(0.55)$ & 1.523 & $(0.34)$ \\
\hline Rwanda & 0.406 & $(0.15)$ & 0.931 & $(0.13)$ & 0.737 & $(0.34)$ & 0.466 & $(0.10)$ & 0.502 & $(0.13)$ & 0.743 & $(0.08)$ \\
\hline Sierra Leone & 0.709 & $(0.11)$ & 1.066 & $(0.15)$ & 0.430 & $(0.08)$ & 1.154 & $(0.23)$ & 0.614 & $(0.07)$ & 1.054 & $(0.12)$ \\
\hline Senegal & 0.952 & $(0.21)$ & 0.767 & $(0.18)$ & 0.705 & $(0.18)$ & 1.125 & $(0.35)$ & 0.780 & $(0.13)$ & 0.854 & $(0.16)$ \\
\hline Swaziland & 0.264 & $(0.13)$ & 0.949 & $(0.29)$ & 0.113 & $(0.11)$ & 6.623 & (5.31) & 0.230 & $(0.09)$ & 1.238 & (0.30) \\
\hline Chad & 0.854 & $(0.15)$ & 0.905 & $(0.09)$ & 0.738 & $(0.14)$ & 0.841 & $(0.10)$ & 0.806 & $(0.11)$ & 0.880 & $(0.06)$ \\
\hline Togo & 0.809 & $(0.32)$ & 0.921 & $(0.19)$ & 0.636 & $(0.32)$ & 0.618 & $(0.15)$ & 0.693 & $(0.20)$ & 0.809 & $(0.12)$ \\
\hline Tanzania & 0.817 & $(0.14)$ & 0.722 & $(0.09)$ & 0.501 & $(0.09)$ & 0.579 & $(0.09)$ & 0.633 & $(0.08)$ & 0.653 & $(0.06)$ \\
\hline Uganda & 0.680 & $(0.20)$ & 0.976 & $(0.18)$ & 0.942 & $(0.42)$ & 0.788 & $(0.23)$ & 0.741 & $(0.18)$ & 0.915 & $(0.14)$ \\
\hline Zambia & 0.678 & $(0.09)$ & 0.988 & $(0.09)$ & 0.542 & $(0.10)$ & 0.593 & $(0.08)$ & 0.635 & $(0.07)$ & 0.841 & $(0.06)$ \\
\hline Zimbabwe & 0.772 & $(0.32)$ & 0.969 & $(0.39)$ & NC & NC & NC & NC & 0.594 & $(0.16)$ & 0.958 & $(0.25)$ \\
\hline
\end{tabular}

Note: All models control for confounding variables. NC: models failed to converge.

Finally, when comparing school attendance for children who were living in a stepfather family arrangement to children living in a single-motherhood family, results show that children living with their stepfather are $10 \%$ less likely to attend school compared to children living with their single mothers. This negative effect is observed in only five countries (Benin, Malawi, Sierra Leone, Swaziland, and Zambia). 


\subsection{Results from the sensitivity analysis}

Table 2 presents results of a sensitivity analysis using the mother-level fixed effect model, which compares school attendance between two children from the same mother but living in different family arrangements - one living with their stepfather and the other living with their biological father. Overall, children aged 6-14 who lived in a stepfather family arrangement were $51 \%$ less likely to attend school compared to their siblings of the same biological mother who lived with their biological father. At country level, these negative results were more pronounced in Benin $(\mathrm{OR}=0.19)$, Côte d'Ivoire $(\mathrm{OR}=0.189)$, Guinea $(\mathrm{OR}=0.28)$, Madagascar $(\mathrm{OR}=0.36)$, Mali $(\mathrm{OR}=0.24)$, Malawi $(\mathrm{OR}=0.35)$, and Tanzania $(\mathrm{OR}=36)$. By age group, there is no difference in school attendance for children aged 6-9. However, children aged 10-14 were $70 \%$ less likely to attend school while living in a stepfather family arrangement

\subsection{Effects of stepfather family arrangement by children's sex}

Figures 5 to 10 present the results of the interaction models between children's sex and family arrangement for the various countries. The interaction models compare the school attendance of male and female children living in the same family arrangement. These results show that female children living in a stepfather family arrangement are not overdiscriminated against compared to male children of the same family arrangement, as reflected by the negative contrasts and the overlap in the confidence intervals of the contrasts.

In Benin, Congo Democratic Republic, Niger, and Chad, female children in two biological parent family arrangements are less likely to attend school compared to male children, as is also the case in stepfather family arrangements. In the other countries, there are no differences in school attendance between male and female children according to their family arrangement. For instance, in Cameroon, female children living with two biological parents are less likely to attend school compared to their male counterparts, whereas this is not the case in a stepfather family arrangement. However, because the confidence interval of these two estimates overlaps, we conclude that they are not (statistically) different, meaning that female children are neither under- nor over-discriminated against. 
Table 2: $\quad$ Sensitivity analysis: Mother-level fixed effect logistic regression analysis showing odds ratios of children's school attendance by family arrangement and children's age in 33 SSA countries; the reference category is both biological parents

\begin{tabular}{|c|c|c|c|c|c|c|}
\hline \multirow{3}{*}{ Country } & \multicolumn{6}{|c|}{ Stepfather } \\
\hline & \multicolumn{2}{|c|}{ 6-9 years } & \multirow{2}{*}{$\begin{array}{l}10-14 \text { years } \\
\text { OR }\end{array}$} & \multicolumn{3}{|c|}{$6-14$ years } \\
\hline & OR & se & & se & OR & se \\
\hline$A / I$ & 1.124 & $(0.35)$ & 0.296 & $(0.09)$ & 0.487 & $(0.05)$ \\
\hline Burkina Faso & & & & & 0.661 & $(0.61)$ \\
\hline Benin & & & & & 0.186 & $(0.10)$ \\
\hline Burundi & & & & & 1.423 & (1.64) \\
\hline Congo Democratic & & & & & 0.511 & $(0.38)$ \\
\hline Congo & & & & & 0.379 & $(0.30)$ \\
\hline Côte d'Ivoire & & & & & 0.192 & $(0.11)$ \\
\hline Cameroon & & & & & 0.197 & $(0.20)$ \\
\hline Ethiopia & & & & & 1.185 & $(0.62)$ \\
\hline Gabon & & & & & 0.948 & (1.05) \\
\hline Ghana & & & & & 0.197 & $(0.17)$ \\
\hline Gambia & & & & & 0.468 & $(0.24)$ \\
\hline Guinea & & & & & 0.284 & $(0.15)$ \\
\hline Kenya & & & & & 0.395 & $(0.25)$ \\
\hline Comoros & & & & & 0.272 & $(0.20)$ \\
\hline Liberia & & & & & 0.860 & $(0.48)$ \\
\hline Lesotho & & & & & 0.332 & $(0.61)$ \\
\hline Madagascar & & & & & 0.357 & $(0.19)$ \\
\hline Mali & & & & & 0.237 & $(0.17)$ \\
\hline Malawi & & & & & 0.348 & $(0.13)$ \\
\hline Mozambique & & & & & 0.805 & $(0.44)$ \\
\hline Nigeria & & & & & 0.785 & $(0.80)$ \\
\hline Niger & & & & & 0.393 & $(0.32)$ \\
\hline Namibia & & & & & 1.802 & $(0.55)$ \\
\hline Rwanda & & & & & 0.565 & $(0.60)$ \\
\hline Sierra Leone & & & & & 0.665 & $(0.30)$ \\
\hline Senegal & & & & & 0.353 & $(0.24)$ \\
\hline Swaziland & & & & & 0.000 & $(0.00)$ \\
\hline Chad & & & & & 0.377 & $(0.22)$ \\
\hline Togo & & & & & 0.000 & $(0.00)$ \\
\hline Tanzania & & & & & 0.359 & $(0.14)$ \\
\hline Uganda & & & & & 1.117 & (1.47) \\
\hline Zambia & & & & & 0.413 & $(0.20)$ \\
\hline Zimbabwe & & & & & 0.128 & $(0.16)$ \\
\hline
\end{tabular}

Note: All models control for children's age and gender. Models are not computed for specific countries for children age $6-9$ years or $10-14$ years due to small sample size. 
Figure 5: Contrast of predictive margins of female versus male children (with 95\% CIs) in each country
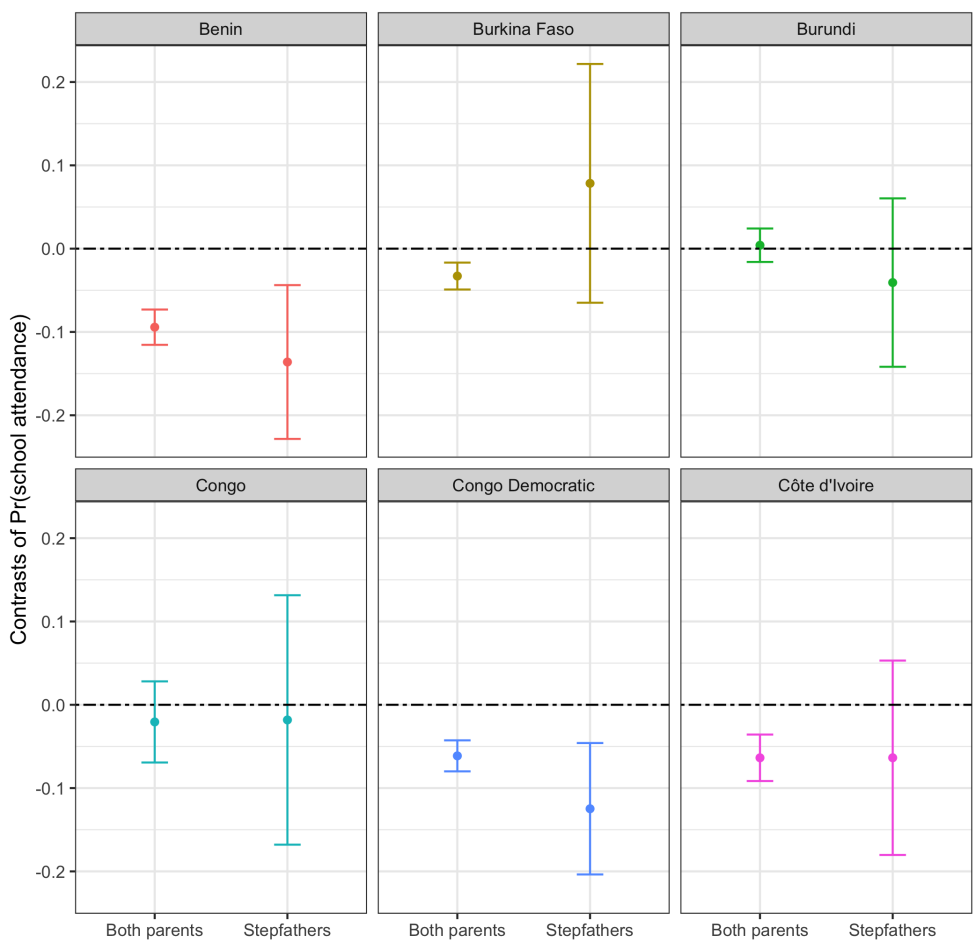
Figure 6: Contrast of predictive margins of female versus male children (with 95\% CIs) in each country
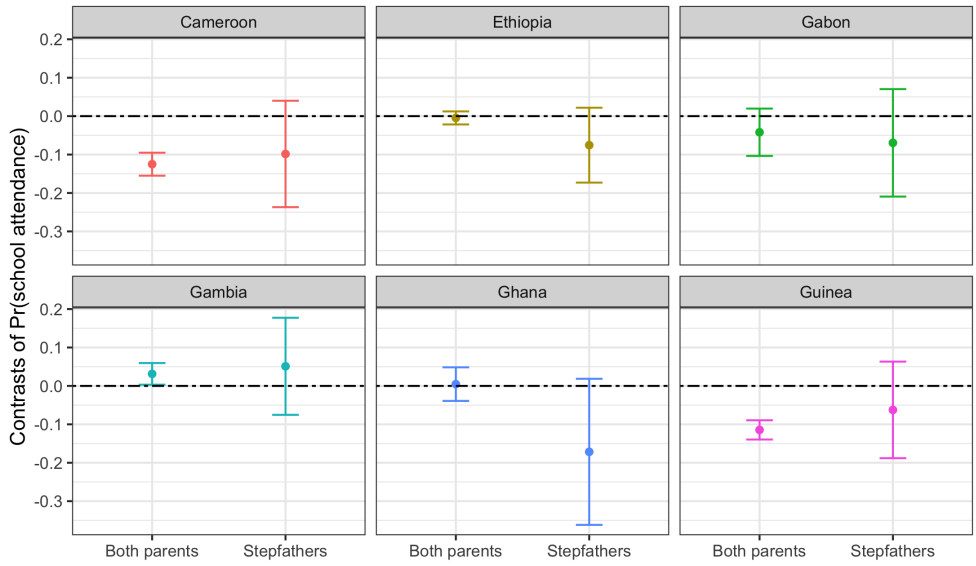

Figure 7: Contrast of predictive margins of female versus male children (with 95\% CIs) in each country
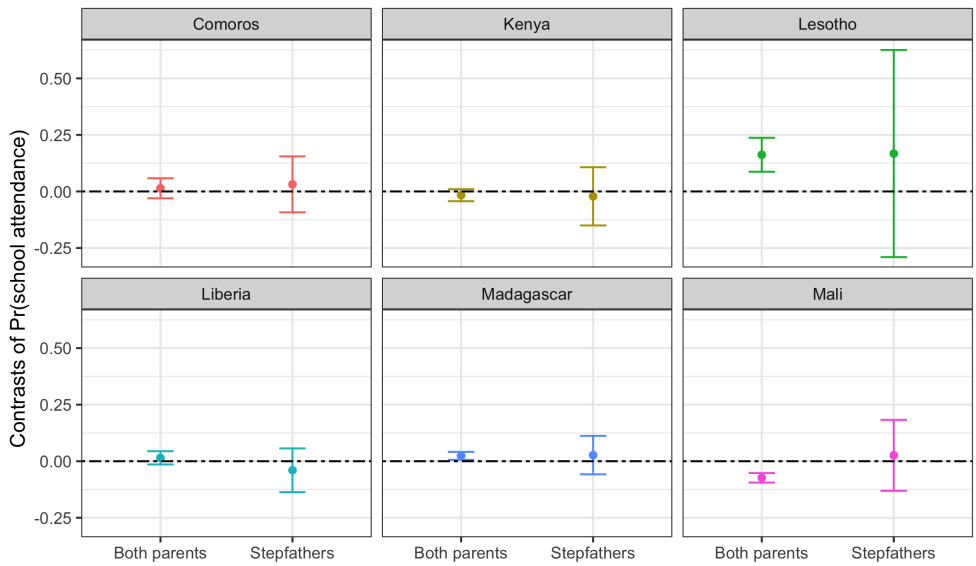
Figure 8: Contrast of predictive margins of female versus male children (with 95\% CIs) in each country
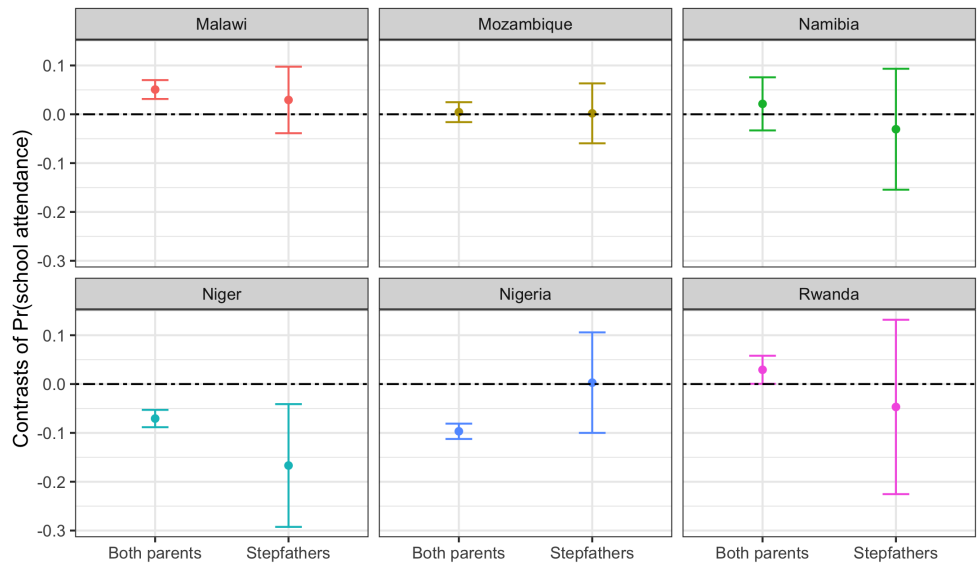

Figure 9: Contrast of predictive margins of female versus male children (with 95\% CIs) in each country
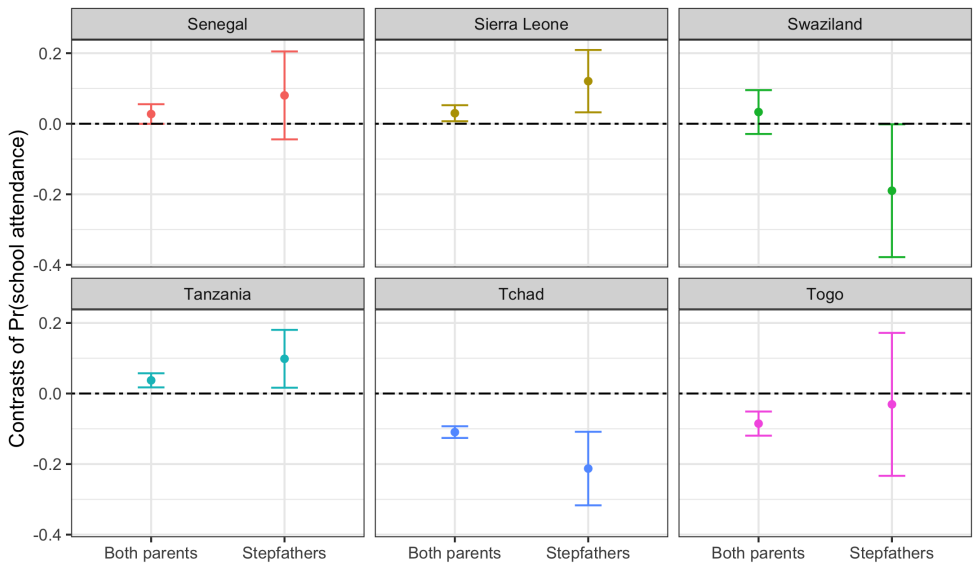


\section{Figure 10: Contrast of predictive margins of female versus male children (with 95\% CIs) in each country}

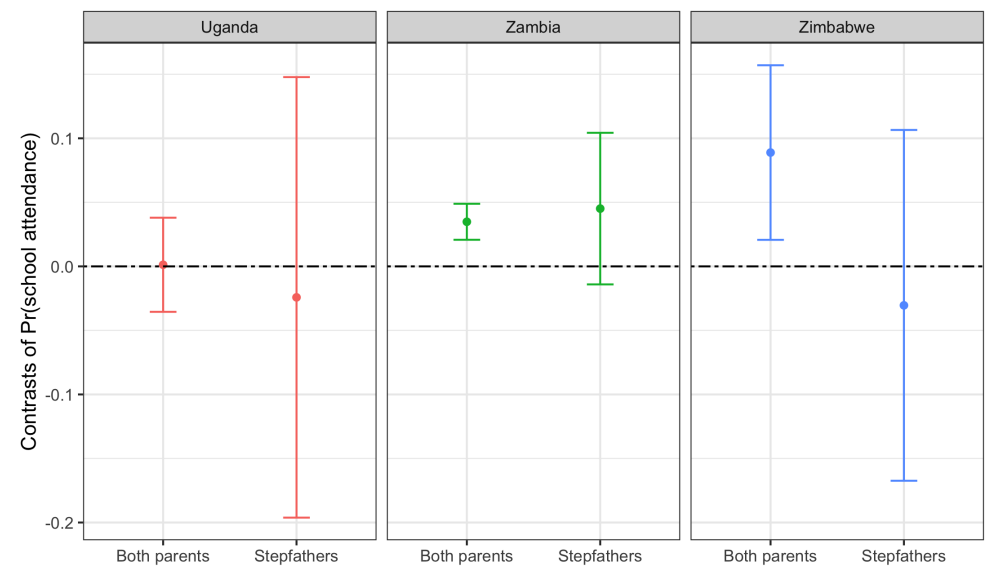

\subsection{Effects of stepfather family arrangement by children's place of residence}

Finally, Table 3 presents the results of the full and sensitivity models of children's schooling by place of residence. These results echoed strongly what was observed in Tables 1 and 2, with a negative effect observed for the school attendance variable in urban and rural areas. However, the negative effect was more pronounced in urban areas compared to rural areas. Rural children aged 6-14 who were living in a stepfather family arrangement were $24 \%$ less likely to attend school compared to children who were living with both of their parents. In urban areas, the odds were $37 \%$ lower. All these results were also supported by the sensitivity analysis. With regard to children living in a single-motherhood arrangement (compared to children living with both parents), the level of the negative effects was similar in urban and rural areas. 
Table 3: Cluster-level and mother-level (sensitivity analysis) fixed effect logistic regression analysis of children's school attendance by family arrangement and place of residence in $33 \mathrm{SSA}$ countries (reference category is both biological parents)

\begin{tabular}{|c|c|c|c|c|c|c|c|c|c|c|c|c|}
\hline \multirow{3}{*}{ Country } & \multicolumn{4}{|l|}{ Urban } & \multicolumn{4}{|l|}{ Rural } & \multicolumn{4}{|c|}{ Sensitivity } \\
\hline & \multicolumn{2}{|c|}{ Stepfather } & \multicolumn{2}{|c|}{$\begin{array}{l}\text { Single } \\
\text { motherhood }\end{array}$} & \multicolumn{2}{|c|}{ Stepfather } & \multicolumn{2}{|c|}{$\begin{array}{l}\text { Single } \\
\text { motherhood }\end{array}$} & \multicolumn{2}{|l|}{ Urban } & \multicolumn{2}{|l|}{ Rural } \\
\hline & OR & se & OR & se & OR & se & OR & se & OR & se & OR & se \\
\hline AII & 0.628 & $(0.03)$ & 0.806 & $(0.03)$ & 0.762 & $(0.02)$ & 0.823 & $(0.02)$ & 0.356 & $(0.08)$ & 0.534 & $(0.06)$ \\
\hline $\begin{array}{l}\text { Burkina } \\
\text { Faso }\end{array}$ & 0.539 & $(0.21)$ & 0.855 & $(0.20)$ & 1.144 & $(0.24)$ & 0.713 & $(0.11)$ & & & & \\
\hline Benin & 0.720 & $(0.17)$ & 1.224 & $(0.27)$ & 0.572 & $(0.08)$ & 0.704 & $(0.10)$ & & & & \\
\hline Burundi & 0.566 & $(0.37)$ & 0.669 & $(0.20)$ & 0.764 & $(0.15)$ & 0.865 & $(0.11)$ & & & & \\
\hline $\begin{array}{l}\text { Congo } \\
\text { Democratic }\end{array}$ & 0.488 & $(0.12)$ & 0.400 & $(0.06)$ & 0.688 & $(0.09)$ & 0.779 & $(0.07)$ & & & & \\
\hline Congo & 0.795 & $(0.46)$ & 0.681 & $(0.26)$ & 0.722 & $(0.15)$ & 0.631 & $(0.11)$ & & & & \\
\hline Côte d'Ivoire & 0.716 & $(0.20)$ & 0.829 & $(0.20)$ & 0.529 & $(0.10)$ & 0.529 & $(0.08)$ & & & & \\
\hline Cameroon & 0.453 & $(0.17)$ & 1.053 & $(0.32)$ & 0.790 & $(0.18)$ & 0.837 & $(0.15)$ & & & & \\
\hline Ethiopia & 0.498 & $(0.18)$ & 0.830 & $(0.17)$ & 0.697 & $(0.10)$ & 0.777 & $(0.07)$ & & & & \\
\hline Gabon & 0.511 & $(0.16)$ & 1.441 & $(0.47)$ & 0.454 & $(0.15)$ & 0.328 & $(0.11)$ & & & & \\
\hline Ghana & 0.534 & $(0.19)$ & 0.710 & $(0.20)$ & 0.962 & $(0.38)$ & 0.447 & $(0.11)$ & & & & \\
\hline Gambia & 0.656 & $(0.18)$ & 1.080 & $(0.27)$ & 0.817 & $(0.15)$ & 1.284 & $(0.28)$ & & & & \\
\hline Guinea & 0.309 & $(0.10)$ & 0.341 & $(0.09)$ & 0.715 & $(0.14)$ & 0.826 & $(0.16)$ & & & & \\
\hline Kenya & 1.163 & $(0.42)$ & 1.031 & $(0.25)$ & 1.323 & $(0.25)$ & 1.059 & $(0.14)$ & & & & \\
\hline Comoros & 0.599 & $(0.24)$ & 0.552 & $(0.30)$ & 0.736 & $(0.16)$ & 0.426 & $(0.11)$ & & & & \\
\hline Liberia & 0.676 & $(0.17)$ & 0.710 & $(0.14)$ & 0.964 & $(0.17)$ & 0.757 & $(0.12)$ & & & & \\
\hline Lesotho & sS & SS & sS & SS & 0.234 & $(0.16)$ & 0.787 & $(0.21)$ & & & & \\
\hline Madagascar & 0.490 & $(0.19)$ & 0.947 & $(0.27)$ & 0.544 & $(0.07)$ & 0.603 & $(0.04)$ & & & & \\
\hline Mali & 1.772 & $(0.87)$ & 0.449 & $(0.14)$ & 0.709 & $(0.15)$ & 1.101 & $(0.27)$ & & & & \\
\hline Malawi & 0.322 & $(0.17)$ & 0.748 & $(0.27)$ & 0.653 & $(0.07)$ & 0.833 & $(0.07)$ & & & & \\
\hline Mozambique & 0.577 & $(0.14)$ & 0.762 & $(0.14)$ & 0.690 & $(0.07)$ & 0.751 & $(0.07)$ & & & & \\
\hline Nigeria & 0.984 & $(0.30)$ & 1.249 & $(0.26)$ & 1.004 & $(0.16)$ & 0.823 & $(0.11)$ & & & & \\
\hline Niger & 0.514 & $(0.26)$ & 0.949 & $(0.20)$ & 0.830 & $(0.15)$ & 0.881 & $(0.16)$ & & & & \\
\hline Namibia & 2.081 & (1.15) & 1.692 & $(0.66)$ & 1.808 & $(0.70)$ & 1.639 & $(0.49)$ & & & & \\
\hline Rwanda & NC & NC & NC & NC & 0.502 & $(0.14)$ & 0.763 & $(0.09)$ & & & & \\
\hline Sierra Leone & 0.554 & $(0.13)$ & 0.773 & $(0.15)$ & 0.638 & $(0.08)$ & 1.228 & $(0.17)$ & & & & \\
\hline Senegal & 0.983 & $(0.35)$ & 0.626 & $(0.16)$ & 0.739 & $(0.14)$ & 1.171 & $(0.31)$ & & & & \\
\hline Swaziland & 0.312 & $(0.46)$ & 1.728 & $(1.42)$ & 0.225 & $(0.09)$ & 1.240 & $(0.33)$ & & & & \\
\hline Chad & 0.541 & $(0.13)$ & 0.872 & $(0.12)$ & 0.942 & $(0.14)$ & 0.860 & $(0.08)$ & & & & \\
\hline Togo & 0.279 & $(0.15)$ & 0.618 & $(0.28)$ & 1.013 & $(0.38)$ & 0.842 & $(0.14)$ & & & & \\
\hline Tanzania & 0.695 & $(0.23)$ & 0.511 & $(0.12)$ & 0.632 & $(0.09)$ & 0.676 & $(0.07)$ & & & & \\
\hline Uganda & 0.339 & $(0.32)$ & 0.744 & $(0.40)$ & 0.759 & $(0.19)$ & 0.952 & $(0.15)$ & & & & \\
\hline Zambia & 0.545 & $(0.10)$ & 0.924 & $(0.12)$ & 0.682 & $(0.09)$ & 0.815 & $(0.08)$ & & & & \\
\hline Zimbabwe & NC & NC & NC & NC & 0.647 & $(0.18)$ & 0.870 & $(0.24)$ & & & & \\
\hline
\end{tabular}

Note: All models control for confounding variables. NC: models didn't converge, SS: small sample size. 


\section{Discussion}

In recent years, several SSA studies have focused on the family arrangements under which children live - as well as the consequences of these arrangements on their well-being or schooling (Chae 2016; Clark and Hamplová 2013; Frantz, Sixaba, and Smith 2015; Lawson et al. 2016; Ntoimo and Odimegwu 2014; Thiombiano, LeGrand, and Kobiané 2013; Tsala Dimbuene and Kuate Defo 2013). However, these studies have not considered the specificity of marriage patterns on a continent characterized by close to universal marriage, a high divorce rate, and a high remarriage rate. This highlights the importance of the stepfamily arrangement for children. The present study adds evidence to the existing literature on family arrangements in sub-Saharan Africa by focusing on the stepfather family arrangement, and it is based on a conceptual framework that matches the realities of the region.

Throughout SSA countries, the family arrangement under which children live has been remarkably durable over time. While the level of remarriage in the region is high, the number of children living in a stepfather family remains low. In fact fewer than 5\% of children live with a stepfather. This is unexpected, but we advance several explanations. The first reason is that alternative systems of child care in SSA, including fosterage, permit women to remarry without bringing their children from previous marriages into their new marriage. Despite a prior expectation that the prevalence of child fostering would decrease over time (as a result of urbanization and modernization), this has not happened, and the situation has remained relatively stable. This can be explained by the stability in the remarriage market - and norms that prevent women from taking another partner's children to a new relationship. The second reason may be that unions are becoming more stable (Clark and Brauner-Otto 2015; Sayi 2015). Greater union stability means that children stay longer with their parents and by the time of the marital disruption, they are old enough to live with their father or with a relative instead of living with their mother. This is particularly the case when the children have to start school. Indeed, the patterns in this study reveal an increased proportion of children who are living with their father either alone or with a stepmother - this proportion ranges from $2 \%$ at age $0-4$ to $7 \%$ for the age group of 10-14 years. The number of children aged 0-4 years living with a stepfather has decreased over the years, implying that there is an increase in the stability of unions in the region (Adjiwanou 2017). Another explanation is the decrease, in recent years, of premarital births in many countries, especially among adolescents; this reduces the number of children who could be living in a stepfather family arrangement (Clark, Koski, and Smith-Greenaway 2017; Hertrich 2017). Also, the fear of contracting diseases such as AIDS may delay many women from remarrying, thereby reducing the proportion of children who might live in a stepfather family arrangement.

There is, however, a possibility that the relatively low percentage of children living

in stepfather family arrangements could be due to measurement error. One concern about 
measurement error is whether the household respondent, who may or may not be the child's parent, accurately appreciates and correctly reports the difference between biological parents and step-parents (even if the question about the biological parent is clear). In SSA, it is common for someone to refer to a man who cares for a child, who happens to be in a union with the child's mother, as the child's father, regardless of whether he is genetically related or not. Such a source of measurement error would result in some children's family arrangements being wrongly classified, hence lowering the proportion of children in stepfamily arrangements. However, the consistency of the results across countries does not strongly support this opinion. Another possibility of misreporting is that the women may be less inclined to report a new relationship in contexts where this is not always viewed well, or simply because the relationship is not yet well consolidated. Furthermore, if the remarried mother has not yet relocated to live with the new partner, she may respond as a single mother, or even as still married to the previous partner. It is well documented that marriage in Africa is a process (Meekers 1992), and remarriage is likely to be a process as well, needing more research within the continent. Future studies should focus on these issues that cannot be addressed by the DHS data.

Stepfather family arrangements are consequential for children's schooling in the region. We found that children who were living with their stepfathers were less likely to attend school compared to children who were living with both biological parents. Children aged 6-9 who were living in a stepfather family arrangement were $18 \%$ less likely to attend school compared to children living with both parents. For children aged 10-14, the effect size increased to $32 \%$. These results are similar to those reported by DeRose (2014). The sensitivity analysis using a women-level fixed effect instead of a cluster-level fixed effect supports these results. However, the negative effect observed previously was eroded for the younger age group of 6-9 years in the sensitivity analysis. This suggests that the negative effect happens only over the age of 9 and that the stepfather family arrangement appears to increase the dropout of older children from school. This may reveal a long-term effect of family instability on children's schooling, although this needs to be confirmed by longitudinal data that follow children over time (Ryan and Claessens 2013). In terms of single motherhood, children in this family arrangement also have a negative school attendance compared to children living with both of their biological parents. The results indicate that children aged 6-9 in a single-mother family are $13 \%$ less likely to attend school compared to children living with both biological parents. For children in the 10-14 years age group living in a single-mother family, results showed that they are $23 \%$ less likely to attend school as compared to those living with both biological parents.

These results confirm that families with both biological parents, either in rural or urban, make up the family arrangement where academic success is the most prevalent among children in SSA. This is the case because it is within this family structure that the gendered stratification of the society plays a strong role in the children's success. In other words, mothers provide nurturing support while the partner brings resources to the home. 
The biological families with both parents are the ones that are more likely to address the changing environment that affects men and women in the region, including economic uncertainties, unemployment, and diseases. However, because this study focuses on one time period, it is not possible to assess how these effects have changed over time.

In this study, we also compared the effects of the stepfather family arrangement on children's schooling to those of the single-motherhood family arrangement. We observed that children aged 6-9 are not discriminated against when they live with a stepfather, which suggests that a stepfather family arrangement is not detrimental to younger children. However, at older ages (10-14 years), children living with a stepfather have lower chances of attending school in comparison to children living with their single mothers. This is in contrast to our postulated hypothesis (H2). This can be explained by the disengagement of the biological father after the repartnering of the mother (with a new partner). It is shown, for instance in the case of South Africa, that the biological father involvement is higher when the children's mother remains divorced, but it becomes intermittent and null when she is repartnered (Madhavan, Richter, and Norris 2016). Thus, if the stepfather didn't bring enough resources to compensate for what was previously provided by the biological father's, the consequences could be devastating to the stepchildren. This is potentially the case when the stepfather brings to the household not only resources but also children from a previous or current marriage (in the case of a polygynous family), in consequence diluting the net resources given to each child (Bougma, LeGrand, and Kobiané 2015).

Throughout the study, we found that the effect of a stepfather is higher for children aged 10-14 years than for children aged 6-9 years. However, this result should be interpreted in a nuanced way, because older children may have dropped out of school before their mother remarried. It is also possible that older children are more likely to engage in conflictual relationships with their stepfather that alter their chances to succeed at school.

All the previous results have been shown to be robust to model misspecifications to the possible selection bias. The sensitivity analysis confirms that children aged 6-14 years in a stepfamily are $51 \%$ less likely to attend school. In the cluster-level fixed effect, this figure was only $24 \%$, although this difference was expected for a number of reasons. First, in the women level fixed effect model, there are no such "all factors held fixed" for the age variables. At the women level, stepchildren are older than their comparison group (siblings with both parents). Thus the observed effect contains not only the effect of a stepfamily but also the effect of age, with increasing age negatively correlated with school attendance.

Although girls are less likely to attend school compared to boys, it was found that they are not over-discriminated against in a stepfather family arrangement. Both boys and girls have an equally lower enrollment rate compared to children living with both biological parents. In a study of orphans in SSA, Case, Paxson, and Ableidinger (2004) showed that the chances of school enrolment were "equally severe" for orphan boys and 
girls and explained it by the fact that orphans are more likely to live with a distant relative. In the case of a stepfather family, it is unclear why no discrimination is found. Future studies should try to resolve this. With regard to urban/rural differences, the results are in line with the postulated Hypothesis 4 - the stepfather family arrangement effect is higher in urban than in rural areas. This could be explained by the fact that the stepfamily arrangement is similar to the situation in Western countries, which has been shown to be very detrimental to children. In rural areas, the stepchildren may benefit more from resources external to their own household.

This study highlights the importance of the stepfather family arrangement on children's well-being in SSA. It is limited to children living with either their mother alone, or with their mother and their biological father or a stepfather. Therefore, children living in a stepfather family arrangement are not representative of all children from remarried women, many of whom are fostered out. It is, however, difficult to determine if they were fostered out before their mother remarried (in anticipation) or because of the remarriage. Furthermore, the results are valid on the assumption that the selection was at the community or household level and not at the children level. Although the various methods used in this study limit the bias from model misspecification, it is still possible that selection could have occurred at the children level.

Another limitation of this study is not being able to assess how the characteristics of the (step)father, other than the household wealth, affect the children's well-being. Thus the effect of the mother should be considered with caution as it also encompasses the characteristics of the (step)father (Adjiwanou, Bougma, and LeGrand 2018). Finally, this study focused mainly on the stepfather family arrangement. Although it is difficult to measure the stepmother family arrangement with DHS data for SSA (because of polygyny in different part of the region), future studies should also assess how living with a stepmother affects children's well-being in the region. Previous studies have suggested that this form of parenting is also detrimental to children, and potentially more so (Chuong and Operario 2012).

African families have undergone transformations over the years and have shown strong resilience to those changes (Ohenaba-Sakyi and Takyi 2006). Although much has been learned and discussed in relation to African families, there are still areas that need to be studied, in accordance with recent transformations and challenges such as urbanization, unemployment, fragility in family kinship, and stretched households, among others. This study was an attempt in this direction and paves the way for a new type of research in SSA that focuses on the various types of family structures under which children live in the region. However, it is still based on the classic typology of the family arrangement, which needs to be improved to match the reality of SSA. Future studies should attempt to fully measure the family structure under which children live in the region by assessing the presence of alternative family members in the household (Madhavan et al. 2017), and especially of grandmothers, who have been shown to positively affect children's school- 
Adjiwanou, Boco \& Yaya: Stepfather families and children's schooling in sub-Saharan Africa

ing (Schrijner and Smits 2018). Studies should also try to fully understand the meaning of stepfather or single-motherhood family arrangements from the perspective of women and men in SSA by assessing these phenomena from a qualitative research perspective. 


\section{References}

Adjiwanou, V. (2017). Step family in sub-Saharan Africa: Trends and consequences on child and adolescent well-being. Paper presented at the Population Association of America, Chicago, United States, April 27-29, 2017.

Adjiwanou, V. and Legrand, T. (2013). Does antenatal care matter in the use of skilled birth attendance in rural africa: A multi-country analysis. Social Science and Medicine 86: 26-34. doi:10.1016/j.socscimed.2013.02.047.

Adjiwanou, V. and LeGrand, T. (2014). Gender inequality and the use of maternal healthcare services in rural sub-saharan africa. Health and Place 29: 67-78. doi:10.1016/j.healthplace.2014.06.001.

Adjiwanou, V., Bougma, M., and LeGrand, T. (2018). The effect of partners' education on women's reproductive and maternal health in developing countries. Social Science and Medicine 197: 104-115. doi:10.1016/j.socscimed.2017.11.054.

Allen, E.S., Baucom, D.H., Burnett, C.K., Epstein, N., and Rankin-Esquer, L.A. (2001). Decision-making power, autonomy, and communication in remarried spouses compared with first-married spouses. Family Relations 50(4): 326-334.

Allison, P. (2009). Fixed-effects regression models (Quantitative Applications in the Social Sciences Book 160). Los Angeles: SAGE Publications.

Amato, P. (2001). Children of divorce in the 1990s: An update of the Amato and Keith (1991) meta-analysis. Journal of Family Psychology 15(3): 355-370. doi:10.1037/0893-3200.15.3.355.

Amoakohene, M. (2004). Violence against women in Ghana: A look at women's perceptions and review of policy and social responses. Social Science and Medicine 59(11): 2373-2385. doi:10.1016/j.socscimed.2004.04.001.

Antoine, P. and Marcoux, R. (2014). Introduction: Pluralité des formes et des modèles matrimoniaux en Afrique un état des lieux. In: Antoine, P. and Marcoux, R. (eds.). Le mariage en Afrique, vol. 1. Quebéc: Presses de l'Université du Quebéc: 1-18.

Antoine, P. and Nanitelamio, J. (1996). Can polygyny be avoided in Dakar? In: Sheldon, K. (ed.). Courtyards, markets and city streets: Urban women in Africa. Boulder: Westview Press: 129-152.

Barbieri, M. and Hertrich, V. (2005). Age difference between spouses and contraceptive practice in sub-Saharan Africa. Population 60(5/6): 617-654.

Beaujot, R. (2000). Les deux transitions démographiques du Québec, 1860-1996. Cahiers québécois de démographie 29(2): 201-230. 
Blanc, A.K. (2001). The effect of power in sexual relationships on sexual and reproductive health: An examination of the evidence. Studies in Family Planning 32(3): 189-213. doi:10.1111/j.1728-4465.2001.00189.x.

Blumberg, R.L. (1984). A general theory of gender stratification. Sociological Theory 2: 23-101.

Bougma, M., LeGrand, T.K., and Kobiané, J.F. (2015). Fertility limitation and child schooling in Ouagadougou: Selective fertility or resource dilution? Studies in Family Planning 46(2): 177-199. doi:10.1111/j.1728-4465.2015.00023.x.

Bove, R. and Valeggia, C. (2009). Polygyny and women's health in sub-Saharan Africa. Social Science and Medicine 68(1): 21-29. doi:10.1016/j.socscimed.2008.09.045.

Bowman, C.G. and Brundige, E. (2014). Child sex abuse within the family in sub-Saharan Africa: Challenges and change in current legal and mental health responses. Cornell International Law Journal 47(2).

Buis, M. (2010). Stata tip 87: Interpretation of interactions in nonlinear models. The Stata Journal 10(2): 305-308.

Caldwell, J.C. (1976). Toward a restatement of demographic transition theory. Population and Development Review 2(3/4): 321-366.

Caldwell, J.C. (2005). On net intergenerational wealth flows: An update. Population and Development Review 31(4): 721-740. doi:10.1111/j.1728-4457.2005.00095.x.

Case, A., Lin, I.F., and McLanahan, S. (2001). Educational attainment of siblings in stepfamilies. Evolution and Human Behavior 22(4): 269-289. doi:10.1016/S10905138(01)00069-1.

Case, A., Paxson, C., and Ableidinger, J. (2004). Orphans in Africa: Parental death, poverty, and school enrollment. Demography 41(3): 483-508. doi:10.1353/dem.2004.0019.

Cebotari, V. and Mazzucato, V. (2016). Educational performance of children of migrant parents in Ghana, Nigeria and Angola. Journal of Ethnic and Migration Studies 42(5): 834-856. doi:10.1080/1369183X.2015.1125777.

Chae, S. (2016). Parental divorce and children's schooling in rural Malawi. Demography 53(6): 1743-1770. doi:10.1007/s13524-016-0521-7.

Cherlin, A.J. (2012). Goode's world revolution and family patterns: A reconsideration at fifty years. Population and Development Review 38(4): 577-607. doi:10.1111/j.17284457.2012.00528.x.

Cherlin, A.J. (2017). Introduction to the special collection on separation, divorce, repart- 
nering, and remarriage around the world. Demographic Research 37(38): 1275-1296. doi:10.4054/DemRes.2017.37.38.

Chuong, C. and Operario, D. (2012). Challenging household dynamics: Impact of orphanhood, parental absence, and children's living arrangements on education in South Africa. Global Public Health 7(1): 42-57. doi:10.1080/17441692.2011.574147.

Clark, S. and Brauner-Otto, S. (2015). Divorce in sub-Saharan Africa: Are unions becoming less stable? Population and Development Review 41(4): 583-605. doi:10.1111/j.1728-4457.2015.00086.x.

Clark, S. and Hamplová, D. (2013). Single motherhood and child mortality in sub-Saharan Africa: A life course perspective. Demography 50(5): 1521-1549. doi:10.1007/s13524-013-0220-6.

Clark, S., Koski, A., and Smith-Greenaway, E. (2017). Recent trends in premarital fertility across sub-Saharan Africa. Studies in Family Planning 48(1): 3-22. doi:10.1111/sifp.12013.

Clark, S., Madhavan, S., Cotton, C., Beguy, D., and Kabiru, C. (2017). Who helps single mothers in Nairobi? The role of kin support. Journal of Marriage and Family 79(4): 1186-1204. doi:10.1111/jomf.12404.

Coleman, J. (1988). Social capital in the creation of human capital. American Journal of Sociology 94: S95-S120.

Coleman, M., Ganong, L., and Fine, M. (2000). Reinvestigating remarriage: Another decade of progress. Journal of Marriage and Family 62(4): 1288-1307. doi:10.1111/j.1741-3737.2000.01288.x.

Crosnoe, R. and Cavanagh, S.E. (2010). Families with children and adolescents: A review, critique, and future agenda. Journal of Marriage and Family 72(3): 594-611. doi:10.1111/j.1741-3737.2010.00720.x.

Cubbins, L.A. (1991). Women, men, and the division of power: A study of gender stratification in Kenya. Social Forces 69(4): 1063-1083. doi:10.2307/2579302.

Dawson, D.A. (1991). Family structure and children's health and well-being: Data from the 1988 National Health Interview Survey on Child Health. Journal of Marriage and Family 53(3): 573-573.

de Walque, D. and Kline, R. (2012). The association between remarriage and HIV infection in 13 sub-Saharan African countries. Studies in Family Planning 43(1): 1-10. doi:10.1111/j.1728-4465.2012.00297.x.

DeRose, L.F. (2014). Household structure and school attendance in 57 countries: Why children with absent fathers do better in some places. Baltimore: University of Mary- 
land (2014-010).

Desai, S. and Andrist, L. (2010). Gender scripts and age at marriage in India. Demography 47(3): 667-687. doi:10.1353/dem.0.0118.

Dial, F.B. (2008). Mariage et divorce à Dakar: Itinéraires féminins. Paris: Karthala.

Diez Roux, A.V. (2001). Investigating neighborhood and area effects on health. American Journal of Public Health 91(11): 1783-1789.

Dodoo, F.N.A. and Frost, A.E. (2008). Gender in African population research: The fertility/reproductive health example. Annual Review of Sociology 34(1): 431-452. doi:10.1146/annurev.soc.34.040507.134552.

Dunn, J. (2002). The adjustment of children in stepfamilies: Lessons from community studies. Child and Adolescent Mental Health 7(4): 154-161. doi:10.1111/14753588.00028 .

Ermisch, J.F. and Francesconi, M. (2001). Family structure and children's achievements. Journal of Population Economics 14(2): 249-270. doi:10.1007/s001480000028.

Folbre, N. (2008). Valuing children: Rethinking the economics of the family. Cambridge: Harvard University Press.

Fouts, H.N. and Brookshire, R.A. (2009). Who feeds children? A child's-eye-view of caregiver feeding patterns among the Aka foragers in Congo. Social Science and Medicine 69(2): 285-292. doi:10.1016/j.socscimed.2009.05.016.

Frantz, J.M., Sixaba, Z., and Smith, M. (2015). A systematic review of the relationship between family structure and health risk behaviours amongst young people: An African perspective. The Open Family Studies Journal 7(1): 3-11. doi:10.2174/1874922401507010003.

Gage, A.J. (1997). Familial and socioeconomic influences on children's well-being: An examination of preschool children in Kenya. Social Science and Medicine 45(12): 1811-1828. doi:10.1016/S0277-9536(97)00113-5.

Garenne, M. (2014). Trends in marriage and contraception in sub-Saharan Africa: A longitudinal perspective on factors of fertility decline. Rockville: ICF International (MEASURE DHS project GPO-C-00-08-00008-00).

Gaydosh, L. (2017). Beyond orphanhood: Parental nonresidence and child well-being in Tanzania. Journal of Marriage and Family 1369-1387. doi:10.1111/jomf.12422.

Goldberg, R.E. (2013). Family instability and early initiation of sexual activity in western Kenya. Demography 50(2): 725-750. doi:10.1007/s13524-012-0150-8.

Goode, W.J. (1993). World changes in divorce patterns. New Haven: Yale University 
Press.

Goody, E. (1982). Parenthood and social reproduction: Fostering and occupational roles in West-Africa. Cambridge: Cambridge University Press.

Grant, M.J. and Yeatman, S. (2014). The impact of family transitions on child fostering in rural Malawi. Demography 51(1): 205-228. doi:10.1007/s13524-013-0239-8.

Hao, L. and Matsueda, R.L. (2006). Family dynamics through childhood: A sibling model of behavior problems. Social Science Research 35(2): 500-524. doi:10.1016/j.ssresearch.2004.10.003.

Heckman, J.J. (2011). The American family in Black and White: A post-racial strategy for improving skills to promote equality. Bonn: National Bureau of Economic Research (NBER) (NBER working paper w16841).

Heise, L.L. (1998). Violence against women: An integrated, ecological framework. Violence Against Women 4(3): 262-290. doi:10.1177/1077801298004003002.

Hertrich, V. (2017). Trends in age at marriage and the onset of fertility transition in sub-Saharan Africa. Population and Development Review 43: 112-137. doi:10.1111/padr.12043.

Indongo, N. and Pazvakawamba, L. (2015). Perceptions of women on marriage in Namibia. Psychology 6: 1413-1420. doi:10.4236/psych.2015.611137.

Izugbara, C. (2016). Single motherhood and neonatal and infant mortality in Sierra Leone, Burkina Faso and Burundi. Public Health 135: 122-130. doi:10.1016/j.puhe.2016.01.017.

John, B. (2018). On marriage dynamics and fertility in Malawi: How does remarriage affect fertility preferences and childbearing behaviour? [PhD thesis]. Cape Town: University of Cape Town.

Kabeer, N. (2016). Gender equality, economic growth, and women's agency: The "endless variety" and "monotonous similarity" of patriarchal constraints. Feminist Economics 22(1): 295-321. doi:10.1080/13545701.2015.1090009.

Kritz, M.M. and Makinwa-Adebusoye, P. (1999). Determinants of women's decisionmaking authority in Nigeria: The ethnic dimension. Sociological Forum 14(3): 399424. doi:10.1023/A:1021495418633.

Lawson, D.W., Schaffnit, S.B., Hassan, A., Ngadaya, E., Ngowi, B., Mfinanga, S.G.M., James, S., and Borgerhoff Mulder, M. (2016). Father absence but not fosterage predicts food insecurity, relative poverty, and poor child health in northern Tanzania. American Journal of Human Biology 1-17. doi:10.1002/ajhb.22938. 
Lesthaeghe, R. (1995). La deuxième transition démographique dans les pays occidentaux: Une interprétation. In: Tabutin, D.T. and Eggerickx Catherine, G. (eds.). Transitions Démographiques et Société. Louvain-la-Neuve/Brussels: Transitions démographiques et sociétés: $133-180$.

LeVine, S. and LeVine, R. (1981). Child abuse and neglect in sub-Saharan Africa. In: Corbin, J. (ed.). Child abuse and neglect: Cross-cultural perspectives. Berkely: University of California Press: $35-55$.

Lloyd, C.B. and Blanc, A.K. (1996). Children's schooling in sub-Saharan Africa: The role of fathers, mothers, and others. Population and Development Review 22(2): 265298. doi:10.2307/2137435.

Locoh, T. and Thiriat, M.P. (1995). Divorce et remariage des femmes en Afrique de l'Ouest. le cas du Togo. Population 50(1): 61-93.

Lopus, S. (2017). Relatives in residence: Relatedness of household members drives schooling differentials in Mozambique. Journal of Marriage and the Family 79(4): 897-914. doi:10.1111/jomf.12393.

Luz, L. and Agadjanian, V. (2015). Women's decision-making autonomy and children's schooling in rural Mozambique. Demographic Research 32(25): 775-796. doi:10.4054/DemRes.2015.32.25.

Madhavan, S., Clark, S., Beguy, D., Kabiru, C.W., and Gross, M. (2017). Moving beyond the household: Innovations in data collection on kinship. Population Studies 71(1): 117-132. doi:10.1080/00324728.2016.1262965.

Madhavan, S., Richter, L., and Norris, S. (2016). Father contact following union dissolution for low-income children in urban South Africa. Journal of Family Issues 37(5): 622-644. doi:10.1177/0192513X14532255.

Manda, S. and Meyer, R. (2005). Age at first marriage in Malawi: A Bayesian multilevel analysis using a discrete time-to-event model. Journal of the Royal Statistical Society: Series A (Statistics in Society) 168(2): 439-455. doi:10.1111/j.1467985X.2005.00357.x.

Mazzucato, V. and Schans, D. (2011). Transnational families and the well-being of children: Conceptual and methodological challenges. Journal of Marriage and the Family 73(4): 704-712. doi:10.1111/j.1741-3737.2011.00840.x.

McLanahan, S. and Percheski, C. (2008). Family structure and the reproduction of inequalities. Annual Review of Sociology 34(1): 257-276. doi:10.1146/annurev.soc.34.040507.134549.

Meekers, D. (1992). The process of marriage in African societies: A multiple indicator 
approach. Population and Development Review 18(1): 61-78. doi:10.2307/1971859.

Mokomane, Z. (2013). Social protection as a mechanism for family protection in sub-Saharan Africa. International Journal of Social Welfare 22(3): 248-259. doi:10.1111/j.1468-2397.2012.00893.x.

Montgomery, M.R. and Hewett, P.C. (2005). Urban poverty and health in developing countries: Household and neighborhood effects. Demography 42(3): 397-425. doi:10.1353/dem.2005.0020.

Ntoimo, L.F. and Odimegwu, C.O. (2014). Health effects of single motherhood on children in sub-Saharan Africa: A cross-sectional study. BMC Public Health 14(1145): 1-13. doi:10.1186/1471-2458-14-1145.

Ohenaba-Sakyi, Y. and Takyi, B.K. (2006). African families at the turn of the 21st century. Westport: Greenwood Publishing Group.

Omariba, D.W.R. and Boyle, M.H. (2007). Family structure and child mortality in subSaharan Africa: Cross-national effects of polygyny. Journal of Marriage and Family 69: 528-543. doi:10.1111/j.1741-3737.2007.00381.x.

Osborne, C. and McLanahan, S.S. (2007). Partnership instability and child wellbeing. Journal of Marriage and Family 69: 1065-1083. doi:10.1111/j.17413737.2007.00431.x.

Pryor, J. (2012). Children's relationships with nonresident parents. In: Pryor, J. (ed.). The international handbook of stepfamilies. Hoboken: John Wiley and Sons: 345-368. doi:10.1002/9781118269923.ch15.

Quisumbing, A.R. (2003). Household decisions, gender, and development: A synthesis of recent research. Baltimore: John Hopkins University Press.

Raley, R.K. and Sweeney, M.M. (2020). Divorce, repartnering, and stepfamilies: A decade in review. Journal of Marriage and Family 82(1): 81-99. doi:10.1111/jomf.12651.

Reher, D.S. (2007). Towards long-term population decline: A discussion of relevant issues. European Journal of Population/Revue Europeenne de Demographie 23(2): 189-207. doi:10.1007/s10680-007-9120-z.

Reniers, G. (2003). Divorce and remarriage in rural Malawi. Demographic Research S1(6): 175-206. doi:10.4054/DemRes.2003.S1.6.

Ribar, D.C. (2004). What do social scientist know about the benefits of marriage? A review of quantitative methodologies. Bonn: Study of Labor (IZA DP 998).

Roby, J.L., Erickson, L., and Nagaishi, C. (2016). Education for children in sub-Saharan 
Africa: Predictors impacting school attendance. Children and Youth Services Review 64: 110-116. doi:10.1016/j.childyouth.2016.03.002.

Rossi, P. (2018). Strategic choices in polygamous households: Theory and evidence from Senegal. The Review of Economic Studies 86(3): 1332-1370. doi:10.1093/restud/rdy052.

Rwezaura, B. (2000). The value of a child: Marginal children and the law in contemporary Tanzania. International Journal of Law, Policy and the Family 14(3): 326-364. doi:10.1093/lawfam/14.3.326.

Ryan, R.M. and Claessens, A. (2013). Associations between family structure changes and children's behavior problems: The moderating effects of timing and marital birth. Developmental Psychology 49(7): 1219-1231. doi:10.1037/a0029397.

Saint-Jacques, M.C., Godbout, É., Drapeau, S., Kourgiantakis, T., and Parent, C. (2018). Researching children's adjustment in stepfamilies: How is it studied? What do we learn? Child Indicators Research 11(6): 1831-1865. doi:10.1007/s12187-017-95107.

Sayi, T.S. (2015). Relationships between marriage and fertility changes in six subSaharan African countries [PhD thesis]. Princeton: Princeton University.

Schrijner, S. and Smits, J. (2018). Grandmothers and children's schooling in sub-Saharan Africa. Human Nature 29(1): 65-89. doi:10.1007/s12110-017-9306-y.

Short Fabic, M., Choi, Y., and Bird, S. (2012). A systematic review of demographic and health surveys: Data availability and utilization for research. Bulletin of the World Health Organization 90(8): 604-612. doi:10.2471/BLT.11.095513.

Sobotka, T. (2008). Overview Chapter 6: The diverse faces of the second demographic transition in Europe. Demographic Research 19(8): 171-224. doi:10.4054/DemRes.2008.19.8.

Stephenson, R. and Elfstrom, K.M. (2012). Community influences on antenatal and delivery care in Bangladesh, Egypt, and Rwanda. Washington: National Center for Biotechnology Information (Public Health Report 3234403): 96-106.

Sweeney, M.M. (2007). Stepfather families and the emotional well-being of adolescents. Journal of Health and Social Behavior 48(1): 33-49. doi:10.1177/002214650704800103.

Sweeney, M.M. (2010). Remarriage and stepfamilies: Strategic sites for family scholarship in the 21st century. Journal of Marriage and Family 72(3): 667-684. doi:10.1111/j.1741-3737.2010.00724.x.

Thiombiano, B.G., LeGrand, T.K., and Kobiané, J.F. (2013). Effects of parental union 
dissolution on child mortality and schooling in Burkina Faso. Demographic Research 29(29): 797-816. doi:10.4054/DemRes.2013.29.29.

Thomas, D. (1990). Intra-household resource allocation: An inferential approach. The Journal of Human Resources 25(4): 635-664. doi:10.2307/145670.

Tilson, D. and Larsen, U. (2000). Divorce in Ethiopia: The impact of early marriage and childlessness. Journal of Biosocial Science 32(3): 355-372. doi:10.1017/S0021932000003552.

Townsend, N., Madhavan, S., Tollman, S., Garenne, M., and Kahn, K. (2002). Children's residence patterns and educational attainment in rural South Africa, 1997. Population Studies 56(2): 215-225. doi:10.1080/00324720215925.

Tsala Dimbuene, Z. and Kuate Defo, B. (2013). Timing of premarital intercourse in Bandjoun (West Cameroon): Does family environment matter? SAGE Open 3(1): 1-15. doi:10.1177/2158244013480152.

Westoff, C.F. (2003). Trends in marriage and early childbearing in developing countries. Calverton: ORC Macro (DHS Comparative Report 5).

Whyte, S.R. and Whyte, M.A. (2011). Children's children: Time and relatedness in Eastern Uganda. Africa 74(1): 76-94. doi:10.3366/afr.2004.74.1.76.

Williams, R. (2012). Using the margins command to estimate and interpret adjusted predictions and marginal effects. The Stata Journal 12(2): 308-331. 


\section{Appendix}

Figure A-1: Weighted proportion of children in family structure, among 33 recent DHS's in SSA, 2006-2015

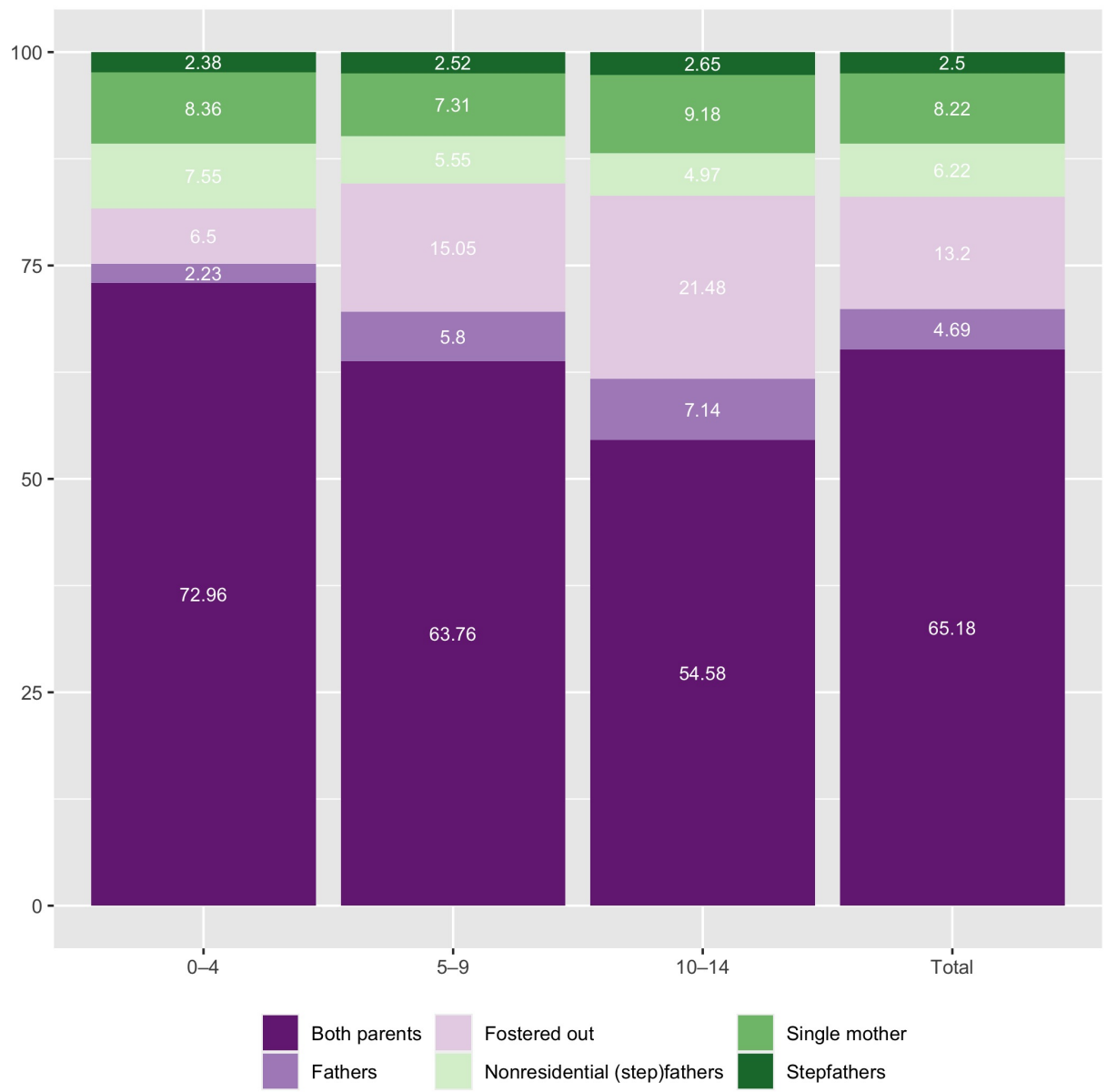


Table B-1: Results from the cluster-level and mother-level (sensitivity analysis) fixed effect logistic regression, odds ratio of attending school by family arrangement, and child age in 33 SSA countries; reference category is single motherhood

\begin{tabular}{|c|c|c|c|c|c|c|c|c|c|c|c|c|}
\hline \multirow{3}{*}{ Country } & \multicolumn{4}{|c|}{$6-9$ years } & \multicolumn{4}{|c|}{$10-14$ years } & \multicolumn{4}{|c|}{$6-14$ years } \\
\hline & \multicolumn{2}{|c|}{ Both parents } & \multicolumn{2}{|c|}{ Stepfather } & \multicolumn{2}{|c|}{ Both parents } & \multicolumn{2}{|c|}{ Stepfather } & \multicolumn{2}{|c|}{ Both parents } & \multicolumn{2}{|c|}{ Stepfather } \\
\hline & OR & se & OR & se & OR & se & OR & se & OR & se & OR & se \\
\hline All & 1.147 & $(0.03)$ & 0.937 & $(0.04)$ & 1.295 & $(0.04)$ & 0.882 & $(0.04)$ & 1.185 & $(0.02)$ & 0.901 & (0.03) \\
\hline & & & & & & & & & & & & \\
\hline & 382 & $(0.25)$ & 1.287 & (0.41) & 1.254 & $(0.23)$ & 1.380 & $(0.43)$ & 1.310 & $(0.16)$ & 1.269 & (0.28) \\
\hline Benin & 1.216 & $(0.20)$ & 0.852 & $(0.20)$ & 1.082 & $(0.18)$ & 0.557 & $(0.13)$ & 195 & $(0.14)$ & 0.723 & $(0.12)$ \\
\hline Burundi & .231 & $(0.19)$ & 1.299 & $(0.37)$ & 1.199 & $(0.25)$ & 0.475 & $(0.17)$ & 1.215 & $(0.15)$ & .903 & $(0.20)$ \\
\hline & & & & & & & & & & & & \\
\hline Cong & 334 & $(0.2$ & & $(0.2$ & & (0. & & & & & & \\
\hline Côte & 1.661 & $(0.3$ & & $(0.2$ & & & & & & & & \\
\hline Cam & 0.948 & $(0.20)$ & & $(0$. & & & & & & & & \\
\hline Eth & 1.191 & (0.1 & 0 & (0.1 & & (0.1 & & (0. & & & & \\
\hline Gabor & 605 & $(0.46)$ & 0.6 & $(0.22)$ & 1.11 & (0.57) & 0.649 & $(0.40)$ & 414 & 32) & .716 & $(0.19)$ \\
\hline Gha & 1.733 & $(0.47)$ & 1.247 & $(0.59)$ & NC & NC & NC & NC & 1.954 & $(0.35)$ & 1.244 & (0.35) \\
\hline & 979 & $(0.20)$ & 1.014 & $(0.31)$ & 0.632 & $(0.18)$ & 0.336 & $(0.12)$ & 0.832 & $(0.14)$ & 0.653 & $(0.14)$ \\
\hline & 1.844 & $(0.41)$ & 2.163 & $(0.73)$ & 1.598 & (0.39) & 0.638 & $(0.21)$ & 1.636 & $(0.26)$ & 0.979 & $(0.22)$ \\
\hline Ken & 0.917 & $(0.14)$ & 1.324 & $(0.39)$ & 184 & $(0.22)$ & .335 & (0.42) & .988 & $(0.11)$ & .238 & $(0.25)$ \\
\hline Comoros & 000 & $(0.62)$ & 1.266 & $(0.48)$ & & $(1.2$ & & (1.71) & 245 & $(0.5$ & 36 & $(0.46)$ \\
\hline Liberia & 1.498 & $(0.22)$ & 1.515 & (0.33) & 0.985 & $(0.23)$ & 0.663 & $(0.21)$ & 1.324 & $(0.16)$ & 126 & $(0.19)$ \\
\hline Lesotho & 1.630 & $(0.54)$ & 0.337 & $(0.35)$ & 1.348 & $(0.5$ & 0.239 & $(0.30)$ & 1.425 & $(0.3$ & 65 & $(0.25)$ \\
\hline Mada & 1.394 & $(0.14)$ & 0.757 & $(0.14)$ & 1.909 & $(0.20)$ & 0.869 & $(0.17)$ & 1.607 & $(0$. & 849 & $(0.11)$ \\
\hline Mali & 1.713 & (0.49) & & $(0.66)$ & & & & & & & & $(0.28)$ \\
\hline Mala & 1.098 & $(0.10)$ & & & & & & & & & & .09) \\
\hline Mozan & 1 & $(0.1)$ & & & & & & & & & & \\
\hline Nigeria & 0.96 & $(0.1$ & & $(0.2$ & 1.250 & $(0.23)$ & 1.434 & $(0.4$ & .049 & & 70 & (0. \\
\hline Niger & & $(0.2$ & & $(0.2$ & & & & & & & & \\
\hline Namibia & 0 & (0.1 & 1.46 & $(0.66)$ & NC & NC & NC & NC & & & & \\
\hline Rwand & & (0.1 & & (0.1 & 2.14 & (0.44) & 1.581 & $(0.77)$ & 45 & (0. & .676 & (0. \\
\hline Sierra Lec & & $(0.1$ & 0.665 & $(0.1$ & 0.866 & $(0.17)$ & 0.372 & $(0.0$ & 0.949 & (0.1 & 0.582 & $(0.09)$ \\
\hline Senegal & 1.305 & $(0.31)$ & 1.242 & $(0.40)$ & 0.889 & $(0.28)$ & 0.627 & $(0.25)$ & 1.171 & $(0.22)$ & 0.914 & $(0.22)$ \\
\hline Swaziland & 1.054 & $(0.32)$ & 0.279 & $(0.15)$ & 0.151 & $(0.12)$ & 0.017 & $(0.02)$ & 0.808 & $(0.20)$ & 0.186 & $(0.08)$ \\
\hline Tchad & 105 & $(0.1$ & 0.9 & $(0.19)$ & 1.189 & $(0.14)$ & 0.878 & $(0.19)$ & .136 & $(0.08)$ & .916 & (0.13) \\
\hline Togo & 086 & $(0.2$ & & $(0.39)$ & 1.617 & $(0.38)$ & 1.028 & $(0.56)$ & .237 & (0.1 & .857 & $(0.28)$ \\
\hline Tanzania & 1.385 & $(0.1$ & 1.1 & $(0.24)$ & 1.727 & $(0.26)$ & 0.866 & $(0.20)$ & 1.531 & $(0.1$ & 0.969 & $(0.14)$ \\
\hline Uganda & .025 & $(0.1$ & 0.697 & $(0.2$ & 1.269 & $(0.38)$ & 1.196 & (0.62) & 1.093 & $(0.16)$ & 0.810 & $(0.22)$ \\
\hline Zambia & 1.012 & $(0.09)$ & 0.686 & $(0.11)$ & 1.686 & $(0.23)$ & 0.915 & (0.19) & 1.189 & $(0.09)$ & 0.755 & $(0.09)$ \\
\hline Zimbabwe & 1.032 & $(0.42)$ & 0.796 & $(0.44)$ & NC & NC & NC & NC & 1.044 & $(0.28)$ & 0.620 & $(0.22)$ \\
\hline
\end{tabular}

Note: All models control for confounding variables. NC: models failed to converge. 
Adjiwanou, Boco \& Yaya: Stepfather families and children's schooling in sub-Saharan Africa

Table B-2: $\quad$ Sample size for the various models

\begin{tabular}{lllllll}
\hline \multirow{2}{*}{ Country } & $\mathbf{6 - 9}$ years & \multicolumn{1}{l}{$\mathbf{1 0 - 1 4}$ years } & $\mathbf{6 - 1 4}$ years & $\mathbf{6 - 1 4}$ years & $\mathbf{6 - 1 4}$ years & $\mathbf{6 - 1 4}$ years \\
\cline { 2 - 7 } & Cluster-level fixed effect & models & Sensitivity & Urban & Rural \\
\hline All & $\mathbf{1 4 1 2 0 3}$ & $\mathbf{9 5 4 2 3}$ & $\mathbf{2 7 7 7 2 6}$ & $\mathbf{8 2 8 0 3}$ & $\mathbf{6 1 1 2 7}$ & $\mathbf{2 1 2 2 8 4}$ \\
Burkina Faso & $\mathbf{7 6 4 8}$ & 6445 & 14956 & 6108 & 2946 & 12010 \\
Benin & 5868 & 4579 & 12198 & 3366 & 3471 & 8727 \\
Burundi & 3598 & 1585 & 6786 & 3400 & 1027 & 5759 \\
Congo & & & & & & \\
Democratic & 7604 & 3787 & 14446 & 4330 & 4045 & 10401 \\
Congo & 1849 & 1037 & 4158 & 515 & 709 & 3449 \\
Côte d'lvoire & 2747 & 2021 & 5281 & 1460 & 1639 & 3642 \\
Cameroon & 2667 & 1824 & 5558 & 1586 & 1383 & 4175 \\
Ethiopia & 6907 & 4856 & 13323 & 6315 & 2081 & 11242 \\
Gabon & 868 & 441 & 2003 & 295 & 1178 & 825 \\
Ghana & 1109 & $\mathbf{N C}$ & 2872 & 523 & 932 & 1940 \\
Gambia & 3345 & 2396 & 6291 & 1772 & 1883 & 4408 \\
Guinea & 3490 & 2758 & 6908 & 2366 & 1794 & 5114 \\
Kenya & 3957 & 2624 & 8913 & 2882 & 2058 & 6855 \\
Comoros & 1268 & 641 & 2477 & 636 & 723 & 1754 \\
Liberia & 2713 & 1320 & 5127 & 865 & 1664 & 3463 \\
Lesotho & 549 & 326 & 1319 & 308 & $\mathbf{S S}$ & 1122 \\
Madagascar & 6656 & 5515 & 13801 & 3658 & 1873 & 11928 \\
Mali & 5374 & 4428 & 10677 & 3735 & 2522 & 8155 \\
Malawi & 8313 & 3878 & 16575 & 3356 & 840 & 15735 \\
Mozambique & 4157 & 2640 & 8164 & 2364 & 1982 & 6182 \\
Nigeria & 10983 & 7643 & 21324 & 4196 & 5741 & 15583 \\
Niger & 6674 & 4896 & 12147 & 5499 & 3046 & 9101 \\
Namibia & 548 & $\mathbf{N C}$ & 1221 & 1221 & 506 & 715 \\
Rwanda & 3411 & 1734 & 7204 & 1767 & $\mathbf{N C}$ & 6335 \\
Sierra Leone & 4634 & 2742 & 8673 & 2014 & 2274 & 6399 \\
Senegal & 2682 & 1866 & 4998 & 1645 & 1460 & 3538 \\
Swaziland & 575 & 183 & 1250 & 273 & 213 & 1037 \\
Tchad & 9490 & 7176 & 18312 & 5987 & 3982 & 14330 \\
Togo & 2456 & 1804 & 5089 & 1410 & 670 & 4419 \\
Tanzania & 4142 & 2962 & 8614 & 3012 & 1340 & 7274 \\
Uganda & 2410 & 929 & 4759 & 1379 & 370 & 4389 \\
Zambia & 7150 & 3531 & 13753 & 5337 & 4487 & 9266 \\
Zimbabwe & 580 & $\mathbf{N C}$ & 1631 & 252 & $\mathbf{N C}$ & 1355 \\
\hline & & & & & & \\
\hline
\end{tabular}

